\title{
Do Minimum Wages in Latin America and the Caribbean Matter? Evidence from 19 Countries
}

\author{
Nicolai Kristensen (COWI), Wendy Cunningham ${ }^{1}$
}

\begin{abstract}
Despite the existence of minimum wage legislation in most Latin American countries, there is little empirical evidence demonstrating its impact on the distribution of wages. In this study, cross-country data for 19 Latin American and Caribbean (LAC) countries is analyzed to gain an understanding of if and how minimum wages affect wage distributions in LAC countries.

Although there is no single minimum wage institution in the LAC region, we find regional trends. Minimum wages affect the wage distribution in both the formal and, especially, the informal sector, both at the minimum wage and at multiples of the minimum. The minimum does not uniformly benefit low-wage workers: in countries where the minimum wage is relatively low compared to mean wages, the minimum wage affects the more disadvantaged segments of the labor force, namely informal sector workers, women, young and older workers, and the low skilled, but in countries where the minimum wage is relatively high compared to the wage distribution, it primarily affects wages of the high skilled. This indicates that the minimum does not generally lift the wages of all, but instead, it offers a wage into which employers can "lock in" wages that are already near that level. Thus, minimum wage legislation is more farreaching than originally thought, affecting both the uncovered informal sector and those earning above the minimum. In addition, the relative level of the minimum wage is important for determining whose wages are affected.
\end{abstract}

This study is part of the regional study "The Role of Minimum Wages in Latin America: Poverty Alleviation, Income Inequality, Employment, and Wages".

Key words: minimum wage, poverty

JEL classification: J38, I38

World Bank Policy Research Working Paper 3870, March 2006

The Policy Research Working Paper Series disseminates the findings of work in progress to encourage the exchange of ideas about development issues. An objective of the series is to get the findings out quickly, even if the presentations are less than fully polished. The papers carry the names of the authors and should be cited accordingly. The findings, interpretations, and conclusions expressed in this paper are entirely those of the authors. They do not necessarily represent the view of the World Bank, its Executive Directors, or the countries they represent. Policy Research Working Papers are available online at http://econ.worldbank.org.

\footnotetext{
${ }^{1}$ Our thanks to Laura Ripani, Lucas Siga, and Andres Lopez for very their helpful research assistance. Also thanks to seminar participants at the World Bank.
} 


\section{Introduction}

The objective of the minimum wage is to guarantee a socially acceptable wage, and thus a decent standard of living, for all workers. ${ }^{2}$ Neoclassical economics predicts that mandating a wage that is higher than the market wage may increase the wages of some low-skilled workers, but at a cost to other low-skilled workers who lose their jobs as employers adjust, whether through higher payments to other workers or a substitution away from labor into capital. A vast literature in the United States and Europe shows that the neoclassical model does not strictly hold since minimum wage legislation seems to have negligible to very small positive impacts on unemployment and wages. ${ }^{3,4}$ The effects that can be statistically identified are primarily limited to teenage workers, who tend to earn wages near the minimum wage, but there is little evidence of any impacts on adult workers. Not surprisingly, the poverty impacts of minimum wages are also absent, due to the fact that minimum wages have little impact on wages or employment and many minimum wage earners in these countries are not among the poor, but instead are young workers who live in non-poor families (Burkhauser, 1996). Together, these facts bring into question the role of the minimum wage as an anti-poverty tool.

Recent literature in Latin America suggests that perhaps we should not dismiss the minimum wage since it seems to have different effects in the specific labor market conditions in the

\footnotetext{
${ }^{2}$ The definition of "socially acceptable" differs by country and across time. The concept of the minimum wage originated in the late 1800s, and was intended to prevent a situation of "sweating," defined as "earnings barely sufficient to sustain existence" (Webb, 1912). As minimum wage institutions developed in Latin America, the "socially acceptable" wage was more generous than in Europe or than in the United States. In many countries, it was intended to cover the food, shelter, clothing, health, leisure, and educational needs of the worker and the family (Starr, 1982).

${ }^{3}$ For a review of the US and European literature, see Brown (1999).

${ }^{4}$ No overall consensus prevails with respect to employment and wage effects of minimum wages. Card and Krueger $(1994,1995)$ find that an increase in the minimum wage in 1992 in the low-skilled fast food industry in New Jersey lead to an increase in the wages of low wage workers. Several studies emerged to test this result, including Machin and Manning (1994), who find similar results for the UK, Neumark and Wascher (1992) who find the opposite result when using a different data set to study the same experiment, and Dolado et al. (1996) who find the opposite result for France.
} 
Region. Specifically, 30-70 percent of Latin American workers are employed in the informal sector (Maloney, 2004), which, by definition, is not bound by a minimum wage; the low-wage population in Latin America includes many adult workers so the results may be more widely felt across the economy; and alternative wage-setting mechanisms developed in Latin America due to, among other factors, hyper-inflation and protectionism.

Turning to the literature, we find that minimum wages have the expected neoclassical impacts in several Latin American countries: a positive effect on formal sector wages and an increase in unemployment rates in the few countries for which studies exist. ${ }^{5}$ The evidence on the impact of minimum wage legislation on the informal sector is mixed: some studies - mostly in Brazil - find that there are positive wage and negative employment effects, as predicted by neoclassical theory for competitive labor markets (Fajnzylber 2002; Maloney and Nuñez, 2004; Neri, Gonzaga, and Camargo 2002; Soares 1998; Foguel, Ramos, Carneiros 2000; Lemos 2002), while others find decreased average wages and increased employment in the informal sector due to the general equilibrium effects of the impacts on the formal sector in a dualistic economy model (Gindling and Terrell 2005 for Costa Rica; Carneiro 2002 for Brazil). Fewer studies examine how the minimum wage affects the overall wage distribution, particularly in the informal sector (Maloney and Nuñez 2005, Lemos 2002, Bell 1997, Neri, Gonzaga, and Camargo 2000, Soares 1998).

This paper examines trends in minimum wage legislation in the Latin America and Caribbean region, rather than focusing on a specific country, by laying out a series of facts to shed light on the institutional and labor market implications for minimum wages in the region. It begins by describing the minimum wage institutions in 24 Latin American countries and shows,

\footnotetext{
${ }^{5}$ Most of the Latin American minimum wage literature is based on analysis of Brazil. There is a smaller collection of papers from Colombia, Chile, Mexico, and Costa Rica. See Annex III of World Bank (2006) for a full review.
} 
not surprisingly, that it is not possible to speak of a single LAC minimum wage institution.

Next, it examines evidence on who the minimum wage earners are in LAC in order to determine if they are few and far between, as in the OECD countries, or if they are a substantial portion of the workforce. Given this background, it expands on the Maloney and Nuñez (2004) eight country analysis ${ }^{6}$ to study the wage distributions of 19 LAC countries to determine if the minimum affects the distribution and whether the institutional factors may contribute to the observed trends.

\section{Minimum Wage Institutions}

\section{Minimum Wage Institutions in LAC}

While all Latin American countries have a legislated minimum wage, there is not a common “minimum wage system” for Latin America and the Caribbean (LAC). Table 1 describes the minimum wage institutions in 24 countries in LAC in terms of: the number of minimum wages, work period covered by the minimum, scope of minimum wage setting, the body that determines the minimum, frequency that it is changed, criteria for adjustment, sub-minimum payments, whether it applies to the public sector, and sanctions for non-compliance. Perhaps the only commonality across the region is that the goal of the systems is to set a wage floor that provides a minimum standard of living for the worker and, in some cases, his/her family. In many countries, minimum wages are Constitutionally mandated, some dating back to the 1930s, when the concept of a minimum wage was new to the world (Starr 1982).

The individual institutions that have developed in Latin America and the Caribbean over time show a wide range of minimum wage levels and categories (Table 1). While Argentina,

\footnotetext{
${ }^{6}$ Argentina, Bolivia, Brazil, Chile, Colombia, Honduras, Mexico and Uruguay. Six of these countries are in the top seven among the 19 countries included in this analysis with respect to per capita GDP.
} 
the Bahamas, Bolivia, Brazil, Haiti, and Trinidad and Tobago are the only countries in LAC with a single minimum wage, and many others have a few well defined minimum wages (two in Colombia and Jamaica; three in Chile; and four in Belize and Peru), some countries, such as the Dominican Republic, Ecuador, Guatemala, Mexico, Paraguay, and Venezuela, have hundreds of legislated minimum wages. Special minimum wages may be set for apprentices, ${ }^{7}$ the public sector, ${ }^{8}$ youth, ${ }^{9}$ workers with disabilities (Argentina, Chile, Honduras, Paraguay), domestic workers (Haiti, Honduras, Nicaragua, Paraguay, and Uruguay), or specific occupations, including soccer players in Peru, the self-employed in Chile, street vendors in the Dominican Republic, bee farmers in Mexico, and bakers in Guatemala. All countries define a minimum wage by time spent working (hour, day, or month), but some have extra legislation by task (Uruguay, Dominican Republic), output quantity (Dominican Republic, and Guatemala), or even horsepower of the equipment (Dominican Republic). The coverage of the minimum wage may be national, ${ }^{10}$ regional (Mexico), by occupation or industry/activity, ${ }^{11}$ task, firm size, or any mix of these (Table 1).

The patterns that emerge from the Latin American institutions suggest that tripartite wage setting is associated with complex minimum wage systems. While the government alone sets the minimum wage in some countries (Brazil, Bolivia, Ecuador, Jamaica, and Uruguay), a tripartite committee comprised of government, worker representatives, and employer representatives is the wage-setting body in others, ${ }^{12}$ while worker and employer representatives set the wage in still

\footnotetext{
${ }^{7}$ Chile, Colombia, El Salvador, Guatemala, Honduras, Paraguay, Trinidad and Tobago, and Venezuela

${ }^{8}$ Brazil, Chile, Guatemala, Panama, Peru, Honduras, Jamaica, Argentina, Ecuador, Dominican Republic, Costa Rica

${ }^{9}$ Argentina, Belize, Chile, Costa Rica, Paraguay, Trinidad and Tobago, and Venezuela

${ }^{10}$ Brazil, Bolivia, Bahamas, Colombia, Chile, Haiti, Trinidad and Tobago, Peru

${ }^{11}$ Belize, Costa Rice Cuba, Dominican Republic, Ecuador, El Salvador, Honduras, Nicaragua

12 Argentina, Bolivia, Colombia, Costa Rica, Dominican Republic, Guatemala, Honduras, Mexico, Nicaragua, Panama, Paraguay, Peru, Trinidad and Tobago, and Venezuela
} 
others (Table 1). Those countries with the most complex wage structure (i.e. hundreds of minimum wages) tend to be those where the wage is set by a tripartite council. ${ }^{13}$

The minimum wage is changed on a regular basis (every six months or annually) in about half the countries, with discretionary changes in others. ${ }^{14}$ Adjustments to the minimum wage may be tied to inflation (in half the countries), GDP fluctuations, the poverty line or market wages (Table 1). In Paraguay and Haiti, the legislation states that inflation rates equal to or higher than 10 percent should trigger a renegotiation of the minimum wage. ${ }^{15}$ Although many countries have a formula to set the minimum wage, in the end, the calculation is fairly random, based on public perceptions of fairness, economic expectations, and a myriad of other criteria that are difficult to weight or quantify in an objective manner.

Sanctions for non-compliance are regulated, but interviews suggest that enforcement is weak. The fines imposed on firms that do not abide by minimum wage laws range from one to 150 times the minimum wage (Table 1). No fines or punishments are legislated in Costa Rica, Jamaica, or Mexico. ${ }^{16}$ In some countries, enforcement is legislated, but not carried out due to a lack of resources - ranging from a lack of vehicles to do inspections to no telephones to receive complaints from workers. The scarce data on enforcement show that fines are rarely imposed. In Chile, for example, 244 fines were issued in 2001 , totalling $\$ 60,000$, as compared to the $\$ 2.9$ million collected in fines for all labor violations that year. This would suggest that minimum

\footnotetext{
${ }^{13}$ If unions and employers define the minimum wage, it is preferred to have multiple minimum wages such that the agreed upon union wage is not imposed on the whole country in the form of a single minimum wage. While it may be argued that the employers will check the wage demands of unions, this does not happen to the extent that it should since wage bargaining is a repeated game where employers risk union retaliation if demands are not met. Thus, the tripartite system may exclude the interests of low wage workers who are inexpensive to fire, relative to union workers.

${ }^{14}$ Argentina, Bahamas, Belize, Dominican Republic, Haiti, Peru, Paraguay, and Trinidad and Tobago

${ }_{10}^{15}$ www.ilo.org/travaildatabase/servlet/minimumwages

${ }^{16}$ Sources: www.ilo.org; individual interviews
} 
wages would have little impact in Latin America, since the wage is paid at the discretion of the employer, with little government oversight, or if there is, little cost of punishment.

\section{International Lessons in Minimum Wage Institutions}

Heterogeneity in minimum wage institutions is not limited to LAC. Across the world, the number of minimum wages, coverage, minimum wage setting mechanisms, and enforcement mechanisms differ. For example, Italy and Germany have hundreds of minimum wages that are negotiated and enforced by unions under a strong contract law framework. Australia’s hundreds of minimum wages are part of a larger labor "awards system” which specifies all remuneration for job types by states (though this is being simplified). In the United States, the federal minimum wage may be over-ridden by the state minimum wage; state inspectors are responsible for enforcement. In Japan, each prefecture (state) has its own minimum wage, which is recommended by local Councils comprised of public interest groups, worker representatives, and employer representatives (Starr 1982).

The US and European experience suggests that complex wage structures are effective if they co-exist with institutions that allow for appropriate wage setting and effective enforceability. While multiple minimum wages are desirable to tailor the "fair" wages to a particular geographic area, skills level, or productivity level, they are only successful if an equally complex system of oversight accompanies them. The Italian and German systems of multiple minimum wages allow for such complexity since they are monitored by the unions that negotiated the contracts. The U.S. system with state-level minimum wage has state inspectors to handle the monitoring and enforcement. Clearly identified actors who monitor specific minimum wages are largely absent in Latin America. 
The OECD minimum wage experience also suggests that minimum wages are better set and enforced if many strategic partners are included in the process but capture is avoided. Governments often do not have the resources to inspect all labor complaints. However, employer and worker representatives, local councils, public interest groups, and NGOs can aid the government by alerting inspectors to specific violations. For this to be effective, such groups need be part of the wage setting process such that they have ownership and the desire to enforce the wages that they helped to set (Starr 1982). However, full representation is necessary, including those who are most at risk of losing from a higher minimum wage. If only union and employers are present, they have the potential to bargain a union wage, and then impose it on the whole country, thus setting a wage that is too high for the lower end of the labor market, where union workers (and their protected jobs, in Latin America) tend not to be.

The complexity of the minimum wage institutions does not allow us to make any conclusions on the effectiveness or quality of such legislation in the LAC region. Instead, we turn to the data to reveal patterns or lessons emerging from the region.

\section{Data, Sample Description and Methodology}

\section{Data}

Nineteen countries were selected for the empirical analysis, based on data availability. They represent a wide variety of countries in the LAC region. They cover different levels of GDP per capita - Argentina is the richest with US\$12,344 per capita (pre-crisis data were utilized) while Nicaragua is the lowest with US\$2,300 per capita ${ }^{17}$ - different country sizes (Brazil to Jamaica) and all geographical regions within LAC. The Caribbean analysis is limited to Dominican

\footnotetext{
${ }^{17}$ For 2000. Source: World Bank "World Development Indicators" published in 2002.
} 
Republic, Guyana, and Jamaica due to an absence of recent household or labor surveys in most Caribbean countries.

Living Standard Measurement Surveys (LSMS), Labor Force Surveys (LFS) or Household Surveys are used (see Table 2 for details). The Dominican Republic survey is from 1997 while the remaining 18 data sets are from 1998 or later (see Table 2).

For each country, the sample is restricted to facilitate comparison across countries and to make the link to minimum wages as clear as possible. The samples include all 16-70 year olds essentially the work force - and only urban households. The latter restriction is mainly due to data limitations, since several of the samples only cover urban households, and the measurement of wages and hours worked in rural areas is particularly complex. We use data only from the metropolitan area in those countries where the data only cover the metropolitan areas or where the minimum wage differs across geographical confines. ${ }^{18}$

We only include individuals who report 30-50 hours worked per week. This restriction is imposed because the treatment of part time work differs by country. In countries that mandate a daily minimum wage, wages of part-time workers can easily be measured. However, in countries that define a monthly minimum wage, the wages of minimum wage workers is less clearly defined. Hence, by restricting the samples to those who work 30-50 hours per week it becomes easier to spot whether or not the minimum wage is binding. ${ }^{19}$ Workers who do not report hours worked are also excluded from the sample.

\footnotetext{
${ }^{18}$ Mexico: Area 1, which includes Mexico City; Chile: Great Santiago; Uruguay: Montevideo. Panama: Region 1, i.e. Panamá, Colón and San Miguelito.

${ }^{19}$ This is not to imply that minimum wages cannot be binding for individuals who work above 50 hours or below 30 hours per week but only that we have a cleaner experiment by imposing this restriction.
} 
"Wage" is defined as the wage income from the primary job of each individual. The selfemployed are thus not included in the analysis, nor are workers with zero (unpaid workers) or with unreported income. All minimum wages are converted to monthly wages in order to allow for general comparisons across the region.

The sample is split into formal and informal sector workers to allow for differential impacts of the minimum wage in the markets where it should (formal) and should not (informal) be binding. This disaggregation also proved to be important in the Maloney and Nuñez (2004) findings. Since only wage earners are included in the sample, the informal self-employed, who comprise approximately 30 percent of LAC labor markets, are not included.

\section{Minimum Wage Variable}

The minimum wage variable is drawn from various official sources and World Bank documents (Table 2). The minimum wages, in local currency, that are used in this paper, as well as their US\$ PPP-adjusted equivalents are given in Table 3. While several countries have multiple minimum wages (Table 1), the most common minimum wage is used for this exercise, in terms of the share of the work force it covers and/or the (geographic) coverage of the household/labor survey being used. If there is not a particularly common minimum wage or the geographic coverage does not dictate which minimum to use, an average minimum wage is used. The countries in the table are ranked from the highest to the lowest PPP-adjusted minimum wage value. The PPP-adjusted value of the minimum wage is the most generous in Paraguay, at $\$ 546$ monthly, and the least generous in Uruguay equaling only $\$ 45$ monthly.

Perhaps a more appropriate benchmark is not the minimum wage in other countries, but

other wages in the local labor market. Figures 1 and 2 present the minimum wage using three 
alternative benchmarks: mean wages, wages of the unskilled working population, and the official poverty line. ${ }^{20}$ The minimum wage is below the mean wage in all countries, ranging from 18 (Uruguay) to 72 percent of mean wages (Paraguay). Half of the sample countries have ratios below 40 percent of the respective mean wages. Venezuela, Guyana, Ecuador and Paraguay all have a ratio above 60 percent. Most European countries have a ratio in the interval of 50 to 60 percent while the US and UK have ratios close to 40 percent.

Maloney and Nuñez (2004) point out that the mean wage is not a good benchmark for the minimum wage, due to outliers in the right tail. They use the median wage as a benchmark and find for their eight country sample, the ratio ranges from 27 percent (Uruguay) to 69 percent (Colombia), which compares to the 18 percent and 52 percent ratios, respectively, of the minimum to mean wage ratio (Figure 1).

Based on this ratio one cannot argue that the minimum wage in, say, Uruguay is too low and that it is too high in Paraguay. Comparison between countries is not valid without conditioning on the skill distribution. If a country has a large dispersion in its level of skills then it would have a wide wage dispersion and a lower ratio of minimum wage to mean wage, and vice versa. Perhaps a more appropriate measure is to compare the minimum wage to the wages of lowskilled workers, whose productivity levels are most similar to those workers who would be minimum wage earners. Presumably, this is one group of workers who should benefit from the minimum wage, and although the educational systems can differ widely between countries it should nevertheless make the ratios more comparable.

Figure 1 shows that even when "controlling” for skill level by a ratio of minimum wage to mean wage of low-skilled workers, the heterogeneity among the 19 countries prevails, and is even amplified. The ratio of the minimum wage to the mean wage of unskilled workers, defined

\footnotetext{
${ }^{20}$ The source of the poverty line used for each country is given in Table 2.
} 
as those with a primary school education or less, ranges from 0.21 (Uruguay) to 1.43 (Paraguay), indicating that the minimum wage is 43 percent higher than the average wage of unskilled workers in Paraguay and 89 percent below the unskilled worker wage in Uruguay. Ten of the 19 sample countries have minimum wages that are more than 70 percent of the average unskilled wage. A similar exercise by Maloney and Nuñez (2004) uses the $10^{\text {th }}$ percentile wage as the base; they show an even higher correlation between the minimum wage and low wage workers. Finally, we examine the level of the minimum wage relative to the official poverty line. ${ }^{21,22}$ The minimum wage is above the poverty line for a household with a single person for all countries except Jamaica, Uruguay, El Salvador, and Mexico (Figure 1) and is up to 6.5 times the poverty line in Guyana. ${ }^{23}$ However, if the minimum wage must stretch to cover the needs of the household, as is mandated in much minimum wage legislation in the Region, it falls short. If a minimum wage worker is supporting both him/herself and a single household dependent (a nonworking household member), it is only sufficient to cover the basic needs in seven of the 17 sample countries (Dominican Republic, Costa Rica, Chile, Honduras, Guyana, Nicaragua, and Peru). Since poor households tend to have more dependents, ${ }^{24}$ the minimum wage will not be sufficient to meet the basic needs of the household, let alone providing for education, leisure, and

\footnotetext{
${ }^{21}$ The official poverty line is commonly calculated as the value of a basic goods consumption basket, which contains the foodstuffs necessary to meet the minimum daily caloric intake of a person (adjusted for sex and age) and the clothing, shelter, and other basic necessities for a minimum standard of living. The value of this basket may be used as a poverty line, while the value of only the food portion of the basket may be used to identify the indigent poor.

${ }^{22}$ The CPI was used to adjust the poverty line to correspond to the year for the individual (household) data. While the CPI is an imperfect adjustment factor since it does not necessarily reflect the evolution in the prices of the basic foods basket items, the price adjustments are only necessary for a few years so the potential bias is not likely to be large. We did not have access to regional deflators and/or regional poverty lines, which could lead to substantial bias. For example, the difference between poverty lines in Lima compared to coastal urban areas in Peru is 25 percent (World Bank, 1999).

${ }^{23}$ Ecuador, Venezuela, and Panama are not included in the exercise since the poverty lines corresponding to the most recent data set were not available, and an appropriate CPI series could not be obtained.

${ }^{24}$ For instance, Mexican households with a per capita income between 0.5 and 0.9 of the poverty line have an average household size of 4.1 persons per household while the average size of households with a per capita income between 1.5 and 2 times the poverty line is 3.2 (ENEU 1999, author's calculations).
} 
other items not included in the basic needs basket that are mandated by much minimum wage legislation. $^{25}$

\section{Sample Description}

Approximately 0.4 percent to 18 percent of the population in the countries in the sample earns the minimum wage. Figure 3 presents the share of the working population earning 0-95\% of the minimum wage, the share earning in the range of $+/-5 \%$ of the minimum wages and are categorized as "minimum wages" earners, ${ }^{26}$ and the share earning more than 5 percent above the minimum wage. In Brazil, Ecuador, Panama and Venezuela, more than 10 percent of the labor force are minimum wage earners, while less than five percent of the labor force are minimum wage earners in 12 of the 15 remaining countries. Notably, three of the four countries with the highest minimum wage to mean wage ratio (Figure 1) also have the largest share of their population earning the minimum wage; Brazil is the outlier, with a large share earning the minimum but a low minimum to mean wage ratio.

Among the sampled countries 0.7 percent to 45 percent of the workforce are sub-minimum wage earners. Most noticeable is the wide variation across countries. At one extreme, five countries have about 40 percent of their workers earning below 95 percent of the minimum wage (Paraguay, Ecuador, Guyana, Nicaragua and Colombia). At the other extreme, less than 3 percent earn below 95 percent of the minimum wage in Mexico, Argentina and Uruguay. The country

\footnotetext{
${ }^{25}$ The discussion does not conclude that minimum wage earners do not cover their basic needs baskets since poor households, in particular, obtain income from other sources, such as social protection mechanisms, remittances, oddjobs, and in-kind payments. Instead, the discussion is intended to give the reader a sense of the level of the minimum wage, using as a benchmark other commonly used statistics.

${ }^{26}$ A range rather than a single value is used to identify minimum wage earners to allow for a certain discrepancy between the stipulated minimum wage and the reported earnings, which, for instance, could arise due to conversion of hourly minimum wages to monthly levels.
} 
ranking of the share of the population earning below the minimum wage is similar to the country ranking of the minimum wage to mean wage ratio, i.e. countries with higher minimum wages are also those with more people earning less than the minimum.

\section{Methodology}

Figure 3 does not reveal very much about how important the minimum wage is to the wage distribution. For example, in Mexico, Argentina and Uruguay, where few workers earn at or below the minimum wage, there might be important effects of the minimum wage for a sub-set of the labor force, or the minimum wage might affect other parts of the wage distribution. A budding minimum wage literature also recognizes the importance of considering the whole wage distribution rather than limiting the analysis to average wage effects at the minimum, as is

common in most literature (Neumark, Schweitzer and Wascher, 2000 for the US; Maloney and Nuñez, 2004 for Colombia; Arango and Pinchon, 2004 for Colombia; Siga and Cunningham, 2005 for Mexico).

We use the methodology presented by DiNardo, Fortin, and Lemieux (1996) and Maloney and Nuñez (2004) to examine the wage distributions of formal and informal sector wages in the 19 country sample, and how the minimum wage may be responsible for the shape of the distribution. Kernel density plots are estimated for each country-sector combination. They are basically a continuous version of discrete histograms, i.e. they smooth a line between each observation $x_{i}$ along the $\mathrm{x}$-axis or group of observations within a certain part (bandwidth) of the x-axis in order to obtain an estimated density. The estimated density can be written as

$$
\tilde{f}(x)=\frac{1}{n h} \sum_{i=1}^{n} K\left(\frac{x-x_{i}}{h}\right)
$$


where $K$ is the Kernel density function, $h$ is the bandwidth, $n$ the number of observations, and $x$ is some point along the $x$-axis. The basic idea is to estimate the density $f(x)$ from the fraction of the sample that is near to $\mathrm{x}$, i.e. the fraction that falls into the bandwidth, $h^{27,28}$

We present both kernel density plots and the cumulative density plots, the latter not requiring any assumptions about bandwidths, thus giving an alternative illustration of the wage distribution. If the kernel density plots show an extremely high concentration at a particular wage, i.e. we see a "spike," and at the same wage, the cumulative distribution becomes vertical i.e. we see a "cliff," then we know that wage are not randomly distributed, but that something is affecting the wage distribution and causing a clustering at that wage. If that wage coincides with the minimum wage, which, as discussed in the institutional description above, is a random wage, then there is a good chance that the minimum wage legislation is the factor behind the spike in the kernel density plot. Alternative influences are also examined later in this paper.

The plots can also test if the minimum wage is binding, give insights into whether it is enforced, and comment on coverage. The minimum wage is binding if wages in, what would otherwise be a continuous distribution, are pulled up to the level of the minimum. If the minimum is set below the market clearing wage, it may still be binding if the minimum wage is used to set wages higher in the minimum wage. It is enforced if it is binding and all individuals covered by the minimum wage legislation (formal sector workers) receive a salary equal to or higher than the minimum wage. If the minimum wage falls below the market clearing level, we cannot say anything about whether or not the minimum wage is enforced. Finally, all formal

\footnotetext{
${ }^{27}$ See Deaton (1997) for a more detailed explanation.

${ }^{28}$ The Epanechnikov kernel is used, as it is the most efficient in minimizing the mean integrated squared error. We allow the bandwidth to differ by the density plot, which allows us to use the smallest bandwidth possible for each country sample. Generally, a bandwidth was chosen to allow for some discontinuities in the kernel density plot, but the location of the spikes were endogenously determined. The smaller the bandwidth, the lower is the risk of bias in the density estimate compared to the true density since less extrapolation is required.
} 
sector workers should be covered by the minimum, since it is a part of the labor benefit that they should receive, by definition, but the informal sector should not be covered, meaning that their kernel density plots should not be affected by the minimum. If they are, then perhaps the minimum wage does bind informal sector wages.

\section{Who Are the Minimum Wage Earners?}

In the U.S. and Europe, the minimum wage has insignificant effects on the wage distribution since so few workers are minimum wage earners. Thus, before examining the wage distributions in LAC, it is useful to understand who are the minimum wage earners, which will give us an indication of whether or not we should expect to see minimum wage effects in the general population or if it is necessary to limit the analysis to certain groups, as is commonly done in OECD countries.

Unlike in the US and Europe, minimum wage earners in LAC are spread across the population (Table 4). For example, while 10-20 percent of workers who define their relationship to the household head as a "child" also claim to earn at or below the minimum wage, 3-10 percent of household heads and 8-20 percent of spouses, also claim this. While 26-70 percent of working 12-17 years olds claim to earn at or below the minimum, Up to 12 percent of prime-aged adults are minimum wage earners or less. And contrary to the US, the proportion of each income quintile that are minimum wage earners decreases by wealth quintile. Thus, it appears that a substantial size of the general work force is at or below the minimum wage, unlike the primarily youth-based minimum wage labor force in OECD countries.

Even if minimum wage workers are distributed across the population, there are still certain groups that are over-represented in the minimum wage labor force. Tables 5 and 6 present the 
share of sub-minimum and minimum wage earners by age, education level, sector of employment, and gender for the 19 country sample. A ratio above 1 indicates that the group is over-represented, relative to their share of the labor force as a whole. The higher the ratio, the more over-represented is the group among the sub-minimum or minimum wage labor force.

Similarly to the OECD countries, young workers are over-represented among minimum and subminimum wage earners. The first column of Table 5 shows that in all but four countries in the sample, those who are age 16-19 are a larger share of the minimum wage population than of the labor force population. Of the countries in the sample, the young are the most over-represented among minimum wage earners in Uruguay (ratio $=2.6$ ), while they are the least over-represented in Paraguay (ratio=0.3) and Ecuador (ratio=0.4). Young workers are even more over-represented among the sub-minimum population (first column of Table 6). Across the region, older workers (age 55-64 years old) are not uniformly over- or under-represented among minimum wage earners.

The less skilled are over-represented in the minimum wage labor force in most of the region. With the exception of Costa Rica, Ecuador, Panama, Paraguay, Peru, and Venezuela, those without any formal education are a larger share of the minimum wage population than of the general working population. This trend is even stronger for the sub-minimum population, where the unskilled are over-represented in all countries. The trends for primary education are similar (Tables 5 and 6).

Employees in the informal sector are over-represented among minimum and sub-minimum wage workers. In all countries except Ecuador, Honduras, Panama, and Paraguay, the ratio in Table 5 is greater than 1, with particularly high ratios in Mexico (3.7), Guatemala (2.0), Chile (1.9), and Brazil (1.8). These trends are reflected in the sub-minimum population. Although it may be argued that the correlation is spurious since informal sector employees tend to be low skilled and thus their marginal productivity may happen to coincide with the minimum wage, later sections of this paper show that this is not necessarily the case. 
Women and the self-employed are neither more nor less likely to be minimum wage workers. Table 5 shows that throughout the region, women's share of the minimum wage population is similar to their share of the working population (near the value of 1). The exceptions are Argentina, Brazil, Honduras, Mexico, and Uruguay, where the ratio is a value of 1.3 or higher. Similarly, women are not necessarily over-represented among the sub-minimum population, though certain outliers emerge, namely Bolivia, Honduras, Mexico, and Uruguay. However, the countries where women are over-represented among minimum wage workers are not necessarily those where they are overrepresented among sub-minimum wage workers. A note of caution is necessary, though, since the table only considers full time workers; expanding the sample to include part time employees, among which women are over-represented, may lead to a different conclusion.

The self-employed are largely under-represented among minimum wage earners. In the small sample where the self-employed could be identified, they were over-represented among the minimum wage earners only in Bolivia, Jamaica, and Mexico, with ratios between 0.14 and 0.9 for the other eight countries in the sample. Conversely, the self-employed are over-represented among the subminimum population in all countries in the sample. This may suggest a greater relative number of workers with very low income in the self-employed sector, with a thinning of the population near the minimum wage. Or, it may suggest a smooth distribution for the self-employed whose incomes we would not expect to be affected by the minimum wage, but a "sweeping up" of low-wage workers whose wages are near the mandated minimum.

Overall, the wages of workers whose marginal productivity is near the minimum wage may converge to the minimum wage. Uruguay, Jamaica, Brazil, Argentina, Mexico, and Bolivia have the lowest ratio of minimum wage workers and also have more women, low educated, and young at the minimum than expected. Thus, even though the minimum wage population is small in these countries, it disproportionately affects certain sectors of the population, which are the groups that are often the hardest to employ, whether due to time constraints (school, family care) that limit job 
choice, training, and job duration for youth and women or due to low human capital of youth (little experience) Conversely, in countries where a high share of the population are minimum or subminimum wage earners - namely Paraguay and Ecuador - women, unskilled, and the young are under-represented among minimum wage earners. Thus, given the distribution of productivity and corresponding wages, the minimum wage may have the effect of sweeping up those whose productivity (and market wage) are near the minimum, but it may not affect the wages of those whose market wage is far from the mandated minimum.

\section{Minimum Wage Effects on the Wage Distribution}

Impacts on the Formal Sector Wage Distribution

Minimum wages affect the formal sector wage distribution in ten of the 19 countries sampled: Brazil, Colombia, Chile, Ecuador, Guyana, Nicaragua, Panama, Paraguay, Peru, and Venezuela. Spikes in the wage distribution for these countries occur at the minimum wage, as shown in the first graph in each row of Figure 4. The "cliffs" in the second graph in each row of Figure 4 confirm the conclusion. The minimum wage seems particularly important in Brazil, where the affect on the wage distribution is indisputable. The results for Ecuador and Guyana are less clear, since they may simply show that the minimum is equal to the average wage for the labor market, resulting in a normal distribution centered on the minimum wage. ${ }^{29}$ There is weaker evidence that the minimum wage affects formal sector wages in Bolivia, El Salvador, Guatemala, Honduras, and Jamaica since the kernel density plots show spikes, but the cumulative density plots do not. The conclusion that there are few cases in which the minimum

\footnotetext{
${ }^{29}$ Figure 3 shows that half the Guyanese and Ecuadorian labor forces earn at or below the minimum wage.
} 
wage definitively affects the formal sector wage distribution in LAC is very much in line with Maloney and Nuñez (2004), though for a smaller set of countries.

Variance in institutional factors do not explain the observation that the minimum wage is binding in the formal sector in some countries but not in others. The countries where the minimum wage affects the formal sector wage distribution do not share any single institutional characteristics: some have a single minimum wage (Brazil) while others have dozens of minimum wage levels (Paraguay, Venezuela), the minimum wages is above the market clearing wage for low-skilled workers in some countries (Paraguay, Ecuador) and below it in others (Brazil, Chile), or its level is centrally established in some (Chile, Brazil) and set by tripartite committee in others (Colombia). In none of these countries is enforcement particularly strong and union power varies (Cunningham and Santamaria, 2003).

The kernel density and cumulative plots in Figure 4 show "spikes" and "cliffs" at wages other than the minimum wage, as well. In some cases, the abrupt changes elsewhere in the distribution are more pronounced than at the minimum wage. This could be due to a "numeraire effect," in which the spikes arise at multiples of the minimum wage ${ }^{30}$ or it may simply be because people tend to report round numbers so the spikes may be a result of measurement error.

In some countries, spikes occur at multiples of the minimum wage, which are not round numbers. Taking as examples Jamaica and Mexico, two countries where the formal sector wage distribution does not show notable disruptions at the minimum, we observe numeraire effects. Notably, the minimum wage is set very low in both countries, and the value of the minimum wage is not a “round number,” being $\$ 3440$ Jamaican dollars weekly and 888 Mexican pesos daily. Figure 5 shows that the minimum wage has pronounced effects throughout the wage

\footnotetext{
${ }^{30}$ This phenomenon has been particularly well documented in Brazil, where spikes at multiples of the minimum wage clearly emerge in several studies using different methodologies (Neri, Gonzaga, and Camargo 2000; Soares 1998; Lemos 2002; Maloney and Nuñez for Colombia 2004).
} 
distributions with clear spikes at multiples of the minimum wage $-1,1.5,2,3$, and 45 times the minimum in Jamaica and 1, 1.25, 2, 2.5, and 3 times the minimum in Mexico - despite the fact that the density of the wage distribution at the minimum wage is low.

Other countries show spikes in the kernel density function at "round numbers." This is the case for El Salvador and possibly Venezuela (Figure 6), where the spikes and cliffs occur at the minimum wage and at round numbers that are not necessarily multiples of the minimum wage. This may be due to employers choosing to pay round wages or due to reporting bias by workers. When the minimum wage is a round number, as in the case for Chile and Venezuela (100,000 in each), it is impossible to disentangle the minimum wage effects from the rounding effects using kernel density plots. Thus, we can be less conclusive about the minimum wage versus rounding effects in these countries.

A final observation is that the minimum wage is not enforced in the formal sector in any country in the sample. Every wage distribution shows full-time workers earning below the minimum wage, even in countries with very low minimum wage levels (Mexico, Uruguay). 


\section{Impacts on Informal Sector Wage Distributions}

Despite the fact that minimum wages are not legally binding in the informal sector, by definition, the kernel density plots and cumulative density plots find that the minimum wage seems to influence the informal sector wage distribution. In 14 of the 19 countries in the sample, a spike was found in the kernel density plot and a cliff was evident in the cumulative density plots at the minimum wage. In addition to those countries for which the minimum affected formal sector wage distributions, effects were found in Bolivia, El Salvador, Guatemala, and Mexico. In the Dominican Republic and Uruguay, a spike was evident, but no cliff was visible in the cumulative density plot. Given the large number of countries for which this phenomenon is observed, it is not surprising that there are no common factors in the minimum wage institutions of the affected labor markets.

In most cases, the "spike" at the vertical minimum wage line is more pronounced for the informal sector than the formal sector wage distributions. This may indicate that the minimum is more binding in the (unskilled) informal sector than in the formal sector, or other factors may be at play. From the labor supply side, the minimum may be a benchmark for "fair" wages. Foguel (1997) argues that workers value not only their absolute wage, but also the wage relative to others of similar skill level. While the exact value of a comparator wage in the formal sector may not be easily measured, the value in terms of minimum wages may be estimated. On the demand side, employers may pay the number of minimum wages comparable to the formal sector market wage for a particular occupation so that their employees will not leave for a similar job in the formal sector, a kind of efficiency wage. Or, they may not be willing to provide all legislated labor benefits, but they may be willing to pay the minimum wage. Finally, the results may be a statistical artifact: since informal sector wages are lower than formal sector wages, the presence of more individuals in the lower part of the distribution - where the minimum wage tends to be - may lead to more of a "piling 
up” around the minimum wage in the informal sector than in the formal sector. Thus, minimum wages may be equally binding in both sectors, but the lower-wages of informal sector workers may give an appearance of being more binding. The empirical evidence from Brazil (Fajnzylber 2002; Neri, Gonzaga and Camargo 2000; Soares 1998) and Mexico (Cunningham and Siga, 2006), which uses panel data to identify the impact of the changes in the minimum wage on the wage distribution, shows that this last explanation is not the case.

\section{Controlling for Skill Level - Low Skilled}

While minimum wage effects are observed across the wage distribution, it is worth “controlling” for the skill level of the population and examining the minimum wage effects for that segment of the population for whom we expect minimum wages to be the most important: the low-skilled. In previous sections, the level of the minimum wage was close to the wages of certain "vulnerable" groups: low-skilled, non-prime age earners, females and non-formal sector workers in countries with a relatively low level of minimum wages compared to the general wage level, but possibly too high to affect vulnerable groups in countries where the minimum wage is relatively high compared to the general wage distribution.

Looking at kernel density plots for the various skill levels for countries with low (Mexico), medium (Brazil), and high (Paraguay, Ecuador) relative minimum wages, we find the same tendency: the minimum wage seems to affect the wage distribution for low-skilled in countries with a low ratio of minimum wages to mean wage, namely Brazil and Mexico (Figure 7). The "cliff" in the cumulative distribution is higher for individuals with no school than it is for primary, which in turn has a more pronounced "cliff" than secondary education. Hence, it seems as if the minimum wage serves to raise the wage above the market clearing level for low skilled more than higher skilled. The equilibrium wage, i.e. the wage determined by market forces, is 
simply too high for high skilled, which probably is the main reason why it appears not to be binding for this group of workers.

However, in countries where the minimum wage/mean wage ratio is relatively high (e.g. Paraguay and Ecuador) the minimum wage affects the wage distribution of low skilled less than the wage distribution of higher skilled (Figure 8). Individuals with high education are still not affected much but the wage distribution of workers with secondary education seems to be more affected by the minimum wage than workers with primary school and in particular more than workers with no school.

Hence, the minimum wages does not generally affect the wage distribution of low-skilled more than it affects the wage distribution of high-skilled. Instead, the results differs depending on the level of the minimum wage relative to the market wages in that country. This has important implications for understanding the role of the minimum wage as a poverty alleviation tool. It indicates that to some extent companies have so much "bargaining power" that they can comply with minimum wages for the group of workers they find should receive this wage and discard the minimum wage if it is too high compared to the skills.

\section{Conclusions}

There is no single minimum wage institution in Latin America and the Caribbean. The wage setting institutions, criteria, coverage, exemptions, periodicity, and enforcement differ greatly across the region. The level of the minimum wage ranges from less than 20 percent of lowskilled wages to 43 percent higher than the low-skilled wage, and from less than the poverty line to more than six times the poverty line. Up to 20 percent of the labor force earns the minimum in some countries and as few as 1 percent in other countries. 
Despite this heterogeneity, there are some regional trends. First, although minimum wages are more evenly distributed across the labor force in LAC than in the OECD countries, minimum wage earners are concentrated among the young, informal sector employees, and low-educated workers. While women are slightly over-represented among minimum wage earners, they do not stand out as much as the other groups.

Second, the minimum wage is more wide-reaching than theory would predict. It affects wages not only in the formal sector, but also in the uncovered informal sector. Kernel density plots show clear "spikes" at the minimum wage, even in countries where the minimum is not a round number. Ten countries demonstrate effects in both sectors, and another four show effects only in the informal sectors. Several countries show spikes at multiples of the minimum wage, suggesting that the minimum is not only useful for affecting wages near the minimum, but also for impacting wages throughout the distribution.

When controlling for skill level, we find that wages "lock in" to the minimum if it is near their wage. Thus, in countries with a low minimum, relative to the mean wage, spikes are seen in the density plots of the least skilled workers, while the spikes are visible among the most skilled workers in countries with high minimum wages.

Finally, the minimum is not enforced in any country in the region. All sample countries show workers in both the formal and informal sectors that earn below the minimum. Perhaps this is not surprising, since enforcement mechanisms are weak, but for some reason employers, and particularly those in the informal sector who are not legally bound by the minimum, choose to adjust wages when the legally mandated wage is changed. This may be due to the use of the minimum as a benchmark for "fair wages" in the economy, regardless of their purchasing power or the criteria for setting them. 


\section{References}

Arango, Carlos, and Angelica Pachon (2003) "Distributive Effects of Minimum Wages on Household Incomes: Colombia 1997-2002,” mimeo (Banco de la Republica/World Bank).

Bell, Linda. (1997) “The Impact of Minimum Wages in Mexico and Colombia” Journal of Labor Economics, July, S102-S135.

Brown, Charlie (1999). "Minimum Wages, Employment and the Distribution of Income” in O. Ashenfelter and D. Card (eds.) The Handbook of Labor Economics, Volume 3b.

Burkhauser, Richard V.; Couch, Kenneth A.; Wittenburg, David C (1996) “'Who Gets What' from Minimum Wage Hikes: A Re-estimation of Card and Krueger's Distributional Analysis in Myth and Measurement: The New Economics of the Minimum Wage” Industrial \& Labor Relations Review 49(3), 547-552.

Card, David and Alan Krueger (1994) "Minimum Wages and Employment: A Case Study of the Fast Food Industry in New Jersey and Pennsylvania", American Economic Review, Vol. 84, No. 4, pp. 772-793.

Card, David and Alan Krueger (1995) "Myth and Measurement: The Economics of the Minimum Wage" (Princeton University Press: Princeton, NJ).

Carneiro, Francisco Galrao (2002) "An Overview of the Effects of the Minimum Wages on the Brazilian Labor Market” in Gill, Indermit, Ricardo Paes de Barros, Andreas Blom (eds.) Brazil Jobs Report, Volume II.

Cunningham, Wendy (2002) “The Poverty Implications of Minimum Wages in Developing Countries” in Gill, Indermit, Ricardo Paes de Barros, Andreas Blom (eds.) Brazil Jobs Report, Volume II, Report No. 24408-BR (World Bank: Washington DC).

Cunningham, Wendy and Mauricio Santamaria (2003) “The Labor Market as a Source of Income Inequality," mimeo, World Bank.

Deaton, Angus (1997) The Analysis of Household Surveys - A Microeconometric Approach to Development Policy, (The Johns Hopkins University Press: Baltimore, USA)

DiNardo, John, Fortin, N.M. and Lemieux, T. (1996) "Labor Market Institutions and the Distribution of Wages, 1973-1992: A Semiparametric Approach", Econometrica v64, n5 (September 1996): 1001-44.

Dolado, J. Kramarz, F. Machin, S., Manning, A. (1996) "Minimum wages - The European Experience", Economic Policy, pp. 317-372.

Fajnzylber, Pablo (2002) "Minimum Wage Effects Throughout the Wage Distribution: Evidence from Brazil's Formal and Informal Sectors.” Universidade Federal de Minais Gerais, Department of Economics and CEDEPLAR, Mimeo, March. 
Foguel, Miguel Nathan (1997) Uma Analise dos Efeitos do Salario Minimo sobre o Mercado de Trabalho no Brasil, Master’s Thesis, PUC-Rio.

Foguel, Miguel, Lauro Ramos, and Francisco Carneiro (2001) The Impact of the Minimum Wage on Labor Market, Poverty, and Fiscal Budget in Brazil, IPEA Texto para Discussao \#839 (IPEA: Rio de Janeiro)

Gindling, T. H. and Katherine Terrell (2005) "The effect of minimum wages on actual wages in formal and informal sectors in Costa Rica” World Development 33(11), 1905

Lemos, Sara (2002) "Robust Quantification of Minimum Wage Effects on Wages and Employment Using a New Data Set - a Menu of Minimum Wage Variables,” mimeo (University College, London)

Machin, S. and Manning, A. (1994) "The Effects of Minimum Wages on Wage Dispersion and Employment: Evidence from the UK Wage Councils", Industrial and Labor Relations Review, January, pp. 319-329.

Maloney, William (2004) “Informality Revisited” World Development 32(7), 1159.

Maloney, William F. and Jairo Nunez (2001) "Measuring the Impact of Minimum Wages: Evidence from Latin America" Policy Research Working Paper No. 2597 (World Bank: Washington, DC).

Neri, Marcelo, Gustavo Gonzaga and Jose Marcio Camargo (2000) Efeitos Informais do Salario Minimo e Pobreza Texto Para Discussao \#724 (IPEA: Rio de Janeiro).

Neumark, David, Wendy Cunningham and Lucas Siga (forthcoming) "The Effects of the Minimum Wage in Brazil on the Distribution of Family Incomes: 1996-2001," Journal of Development Economics.

— Mark Schweitzer, and William Wascher (forthcoming) "Minimum Wage Effects throughout the Wage Distribution” Journal of Human Resources.

and W. Wascher (1992) "Employment Effects of Minimum Wages and Subminimum Wages: Reply to Card, Katz and Krueger", Industrial and Labor Relations Review, Vol. 46, pp. 55-81.

and W. Wascher (1997) "Do Minimum Wages Fight Poverty", NBER WP\#6127.

Siga, Lucas and Wendy Cunningham (2003) "Wage and Employment Effects of Minimum Wages on Vulnerable Groups in the Mexican Labor Market,” World Bank/LCSHS mimeo (World Bank: Washington, DC).

Soares, Sergei (2002) "O Impacto Distributivo do Salario Minimo: A Distribucao Individual dos Rendimentos do Trabalho,” IPEA Texto para Discusao No. 873. 
Starr, Gerald (1982) Minimum Wage Fixing: An International Review of Practices and Problems (ILO: Geneva).

Webb, Sidney (1912) “The Economic Theory of a Legal Minimum Wage” Journal of Political Economy 20(10): 973-998.

World Bank (2002) "Paraguay - Attacking Poverty", Vol 1.

World Bank (1999) "Poverty and Social Developments in Peru", 1994-1997".

World Bank (2006) Minimum Wages in Latin America and the Caribbean: the Impact on Employment, Inequality, and Poverty, LCRCE/mimeo. 
Table 1. Main Institutional Characteristics Affecting Minimum Wages in Selected Latin American Countries

\begin{tabular}{|c|c|c|c|c|c|c|c|c|c|c|}
\hline Country & $\begin{array}{l}\text { Number of } \\
\text { minimum } \\
\text { wages }\end{array}$ & $\begin{array}{l}\text { Work period } \\
\text { covered by } \\
\text { the } \mathbf{m w}\end{array}$ & $\begin{array}{l}\text { Scope of mw } \\
\text { setting }\end{array}$ & $\begin{array}{l}\text { Body that } \\
\text { sets the mw }\end{array}$ & $\begin{array}{l}\text { Frequency } \\
\text { changed }\end{array}$ & $\begin{array}{l}\text { Criteria for } \\
\text { adjustment }\end{array}$ & $\begin{array}{l}\text { Sub- } \\
\text { minimum } \\
\text { payments }\end{array}$ & $\begin{array}{l}\text { Mw applied } \\
\text { to public } \\
\text { sector }\end{array}$ & $\begin{array}{l}\text { Sanctions } \\
\text { for non- } \\
\text { compliance }\end{array}$ & Notes \\
\hline & & $\begin{array}{c}\text { monthly (M), } \\
\text { weekly (W), } \\
\text { daily(D), } \\
\text { hourly (H), } \\
\text { by task (T), } \\
\text { by output } \\
(\mathrm{O})\end{array}$ & $\begin{array}{c}\text { National } \\
(\mathrm{N}), \\
\text { regional (R), } \\
\text { sector }(\mathrm{S}), \\
\text { occupation } \\
(\mathrm{O}), \\
\text { task (T), } \\
\text { firm size } \\
(\mathrm{W})\end{array}$ & $\begin{array}{c}\text { Government } \\
\text { (G) or } \\
\text { Tripartite } \\
\text { (T); in order } \\
\text { of } \\
\text { dominance }\end{array}$ & & $\begin{array}{c}\text { inflation (I), } \\
\text { needs of } \\
\text { worker \& } \\
\text { family (N), } \\
\text { cost of living } \\
\text { (L), } \\
\text { ec development } \\
\text { (D), } \\
\text { labor market } \\
\text { conditions (M), } \\
\text { firm capacity to } \\
\text { pay (C), equity } \\
\text { (E), } \\
\text { other/unclear/ } \\
\text { political (O) }\end{array}$ & & & & \\
\hline Argentina & 1 & $\mathrm{M}, \mathrm{H}$ & $\mathrm{N},(\mathrm{S}, \mathrm{O})$ & $\mathrm{T}$ & discretion & $\mathrm{N}, \mathrm{E}$ & \begin{tabular}{|} 
workfare \\
programs, \\
disabled \\
workers, \\
trainees, youth
\end{tabular} & own & $\begin{array}{l}\$ 250 \text { to } \\
\$ 1000 \text { per } \\
\text { worker }\end{array}$ & d,h \\
\hline Bahamas & 1 & $\mathrm{~W}, \mathrm{H}$ & $\mathrm{N}$ & $\mathrm{G}, \mathrm{T}$ & discretion & $\mathrm{O}$ & no & yes & N/A & \\
\hline Belize & 4 & $\mathrm{H}$ & I & $\mathrm{T}, \mathrm{G}$ & discretion & $\mathrm{O}$ & students & yes & N/A & \\
\hline Bolivia & 1 & $\mathrm{M}$ & $\mathrm{N}$ & G & annual & I, N, D & no & yes & N/A & $c, \mathrm{i}$ \\
\hline Brazil & 1 & M & $\mathrm{N}$ & G & annual & I & no & own & $\begin{array}{c}\$ 170 \text { per } \\
\text { worker }\end{array}$ & \\
\hline
\end{tabular}




\begin{tabular}{|c|c|c|c|c|c|c|c|c|c|c|}
\hline Country & $\begin{array}{l}\begin{array}{l}\text { Number of } \\
\text { minimum } \\
\text { wages }\end{array} \\
\end{array}$ & $\begin{array}{l}\text { Work period } \\
\text { covered by } \\
\text { the } \mathbf{m w}\end{array}$ & $\begin{array}{l}\text { Scope of mw } \\
\text { setting }\end{array}$ & $\begin{array}{l}\text { Body that } \\
\text { sets the mw }\end{array}$ & $\begin{array}{l}\text { Frequency } \\
\text { changed }\end{array}$ & $\begin{array}{l}\text { Criteria for } \\
\text { adjustment }\end{array}$ & $\begin{array}{l}\text { Sub- } \\
\text { minimum } \\
\text { payments } \\
\end{array}$ & $\begin{array}{l}\text { Mw applied } \\
\text { to public } \\
\text { sector }\end{array}$ & $\begin{array}{l}\text { Sanctions } \\
\text { for non- } \\
\text { compliance }\end{array}$ & Notes \\
\hline Chile & 3 & M & $\mathrm{N}$ & $\mathrm{G}, \mathrm{T}$ & annual & I. L, M, O & $\begin{array}{l}\text { under } 18, \\
\text { apprentices, } \\
\text { over } 65, \\
\text { mentally } \\
\text { disabled } \\
\text { workers }\end{array}$ & own & $\begin{array}{l}\text { Fines by } \\
\text { firm size }\end{array}$ & $\mathrm{f}$ \\
\hline Colombia & 2 & $\mathrm{D}$ & $\mathrm{N}$ & $\mathrm{T}, \mathrm{G}$ & annual & $\mathrm{L}, \mathrm{M}, \mathrm{C}, \mathrm{I}, \mathrm{G}$ & apprentice & yes & $\begin{array}{c}1 \text { to } 100 \mathrm{x} \\
\text { mw }\end{array}$ & \\
\hline Costa Rica & 25 & $\mathrm{H}, \mathrm{D}, \mathrm{M}$ & $\mathrm{S}, \mathrm{O}$ & $\mathrm{T}$ & 6 month & I, L, D & Youth & own & 1 to $23 \mathrm{mw}$ & e \\
\hline Cuba & 6 & N/A & $\mathrm{O}, \mathrm{S}$ & $\mathrm{G}, \mathrm{T}$ & N/A & $\mathrm{D}, \mathrm{E}$ & no & yes & N/A & \\
\hline $\begin{array}{l}\text { Dominican } \\
\text { Republic }\end{array}$ & $\begin{array}{c}\sim 271 \\
\text { (by sector) }\end{array}$ & $\mathrm{M}, \mathrm{D}, \mathrm{T}, \mathrm{H}, \mathrm{O}$ & $\mathrm{S}, \mathrm{O}, \mathrm{T}$ & $\mathrm{T}$ & discretion & $\mathrm{N}, \mathrm{L}, \mathrm{M}, \mathrm{C}$ & No & own & 3 to $6 \mathrm{mw}$ & $\mathrm{f}$ \\
\hline Ecuador & $\begin{array}{c}\sim 150 \\
\text { (by sector) }\end{array}$ & M & $\mathrm{S}, \mathrm{O}$ & G & 6 months & I & No & own & 2 to $5 \mathrm{mw}$ & \\
\hline El Salvador & 8 & $\mathrm{D}$ & $\mathrm{S}, \mathrm{T}$ & $\mathrm{G}, \mathrm{T}$ & 3 years & $\mathrm{N}, \mathrm{L}, \mathrm{D}, \mathrm{O}$ & apprentices & yes & N/A & \\
\hline Guatemala & $\begin{array}{c}\text { Hundreds } \\
\text { (by sector) }\end{array}$ & $\mathrm{D}, \mathrm{O}$ & S, I & $\mathrm{T}, \mathrm{G}$ & annual & $\mathrm{L}, \mathrm{N}, \mathrm{M}, \mathrm{C}$ & apprentices & own & $\begin{array}{l}\text { Fines/ } \\
\text { prison }\end{array}$ & \\
\hline Haiti & 然 & $\mathrm{D}$ & $\mathrm{N}$ & $\mathrm{G}, \mathrm{T}$ & discretion & L, I & $\begin{array}{l}\text { Domestic } \\
\text { workers }\end{array}$ & yes & N/A & \\
\hline Honduras & 12 & $\mathrm{D}$ & S, W & $\mathrm{T}, \mathrm{G}$ & 6 months & $P, L, G, C, I$ & $\begin{array}{c}\text { Apprentices, } \\
\text { disabled } \\
\text { workers } \\
\end{array}$ & no & $\$ 30$ to $\$ 300$ & \\
\hline Jamaica & 2 & $\mathrm{~W}, \mathrm{H}$ & $\mathrm{N}, \mathrm{O}$ & G & $1-3$ years & $\mathrm{I}, \mathrm{N}$ & casual labor & own & none & \\
\hline Mexico & 91 & $\mathrm{D}$ & $\mathrm{R}, \mathrm{O}$ & $\mathrm{T}$ & $\begin{array}{c}\text { yearly/ } \\
\text { discretion }\end{array}$ & $\mathrm{N}, \mathrm{D}, \mathrm{C}, \mathrm{I}, \mathrm{L}, \mathrm{M}$ & $\begin{array}{c}\text { part-time } \\
\text { workers }\end{array}$ & yes & $\begin{array}{l}\text { none under } \\
\text { federal law }\end{array}$ & \\
\hline
\end{tabular}




\begin{tabular}{|c|c|c|c|c|c|c|c|c|c|c|}
\hline Country & $\begin{array}{l}\text { Number of } \\
\text { minimum } \\
\text { wages }\end{array}$ & $\begin{array}{l}\text { Work period } \\
\text { covered by } \\
\text { the } \mathrm{mw}\end{array}$ & $\begin{array}{l}\text { Scope of mw } \\
\text { setting }\end{array}$ & $\begin{array}{l}\text { Body that } \\
\text { sets the mw }\end{array}$ & $\begin{array}{l}\text { Frequency } \\
\text { changed }\end{array}$ & $\begin{array}{l}\text { Criteria for } \\
\text { adjustment }\end{array}$ & $\begin{array}{l}\text { Sub- } \\
\text { minimum } \\
\text { payments }\end{array}$ & $\begin{array}{l}\text { Mw applied } \\
\text { to public } \\
\text { sector }\end{array}$ & $\begin{array}{l}\text { Sanctions } \\
\text { for non- } \\
\text { compliance }\end{array}$ & Notes \\
\hline Nicaragua & 12 & M, D & $S$ & $\mathrm{~T}$ & $\begin{array}{l}6 \text { month - } \\
1 \text { year }\end{array}$ & $\mathrm{N}, \mathrm{D}$ & $\begin{array}{l}\text { domestic } \\
\text { workers }\end{array}$ & yes & $25 \% \mathrm{mw}$ & b \\
\hline Panama & 30 & $\mathrm{H}$ & $\mathrm{R}, \mathrm{S}, \mathrm{W}$ & $\mathrm{G}, \mathrm{T}$ & 2 years & $\mathrm{L}, \mathrm{D}, \mathrm{C}, \mathrm{O}$ & No & no & $\$ 25$ to $\$ 150$ & \\
\hline Paraguay & $\begin{array}{c}\text { Hundreds } \\
\text { (by sector) }\end{array}$ & M, D & $\mathrm{N}, \mathrm{O}, \mathrm{S}$ & $\mathrm{T}, \mathrm{G}$ & discretion & $\mathrm{N}, \mathrm{L}, \mathrm{M}, \mathrm{C}, \mathrm{O}$ & $\begin{array}{c}\text { Apprentices, } \\
\text { youth, } \\
\text { disabled } \\
\text { workers, } \\
\text { domestic } \\
\text { workers } \\
\end{array}$ & no & 10 to $30 \mathrm{mw}$ & $\mathrm{a}$ \\
\hline Peru & 4 & M & $\mathrm{N}$ & $\mathrm{T}, \mathrm{G}$ & discretion & $\mathrm{N}, \mathrm{D}$ & no & no & $\begin{array}{l}\text { Fines by } \\
\text { firm size }\end{array}$ & g \\
\hline $\begin{array}{l}\text { Trinidad } \\
\text { and Tobago }\end{array}$ & 1 & $\mathrm{H}, \mathrm{D}, \mathrm{W}, \mathrm{M}$ & $\mathrm{N}$ & $\mathrm{T}, \mathrm{G}$ & discretion & $\mathrm{L}, \mathrm{M}, \mathrm{D}, \mathrm{C}$ & $\begin{array}{l}\text { Trainees, } \\
\text { apprentices, } \\
\text { workfare, } \\
\text { students, } \\
\text { volunteers }\end{array}$ & yes & N/A & \\
\hline Uruguay & 21 & $\mathrm{M}, \mathrm{D}, \mathrm{T}$ & $\mathrm{N}, \mathrm{R}, \mathrm{S}, \mathrm{O}$ & G & Annual & $\mathrm{N}, \mathrm{D}, \mathrm{C}, \mathrm{I}, \mathrm{O}$ & $\begin{array}{l}\text { Domestic or } \\
\text { rural workers }\end{array}$ & no & $\begin{array}{l}1 \text { to } 150 \mathrm{mw} \\
\text { per worker }\end{array}$ & \\
\hline Venezuela & $\begin{array}{c}\text { Hundreds } \\
\text { (by sector) }\end{array}$ & M & $\mathrm{R}, \mathrm{S}, \mathrm{I}, \mathrm{O}$ & $\mathrm{T}, \mathrm{G}$ & annual & $P, G, L$ & $\begin{array}{c}\text { Apprentices, } \\
\text { youth }\end{array}$ & yes & N/A & $\mathrm{a}$ \\
\hline
\end{tabular}

Source: interviews with Labor Ministries; Gonzaga and Scandiuzzi (1998); Ruiz (2001); Starr (1993); www1.umn.edu/humanrts/esc/bolivia2001.html; www.salaryexpert.com/seco/careerjournal/hrcodes/COUNTRIES.htm; www.ilo.org/public/english/dialogue/govlab/legrel/papers/brfnotes/minwages;

www.mintrab.cl; www.mtps.gob.pe; www.stps.gov. $m x ;$ www.set.gov.do/legislacion/salariomin/index.htm; www.ilo.org/travaildatabase/servlet/minimumwages; www.dol.gov/ILAB/media/reports/oiea/wagestudy.

a) Automatic adjustment if the inflation rate rises by $10 \%$ or more

b) Fines are rarely imposed, only large firms are generally inspected

c) Incomplete information since the Department of labor inspection is located outside ministry and without phones

d) Enforcement generally at regional level - no information presently available 
e) The Ministry does not impose fines; it only warn and takes to court.

f) Codigo del trabajo Art 44 \& Art 477: firms with 1 to 49 workers: $\$ 40$ to $\$ 800$ monthly per worker affected. Firms with 50 to 199 workers: $\$ 80$ to $\$ 1600$ monthly per worker affected. firms with over 200 workers: $\$ 120$ to $\$ 2400$ monthly per worker affected.

g) The fines are a function of the number of workers and the number of infractions. Fines range from the equivalent of US\$200 for first infraction with 1-5 workers to US $\$ 1800$ for multiple infractions involving hundreds of workers.

h) Legally, 1500 minimum wages are on the books, as a result of the bargaining under the military dictatorship. In practice, though, only one minimum wage applies.

i) According to Article 121 of the Supreme Decree 21615, (29 May, 1987), the Labor Judges may impose a fine of \$1,000 -10,000 bolivianos, for infractions

1. N/A indicates that the data are not available 
Table 2. Data sources

\begin{tabular}{|c|c|c|c|}
\hline Country & Household/individual data & Minimum wage & Poverty line \\
\hline Argentina & $\begin{array}{l}\text { Household Survey: Encuesta } \\
\text { Permanente de Hogares }\end{array}$ & $\begin{array}{l}\text { INDEC (Instituto Nacional de Estadistica y } \\
\text { Censos }\end{array}$ & $\begin{array}{l}\text { Government's official poverty line } \\
\text { by INDEC (Instituto Nacional de } \\
\text { Estadistica y Censos) }\end{array}$ \\
\hline Bolivia & Household Survey & $\begin{array}{l}\text { Instituto Nacional de Estadistica de } \\
\text { Bolivia. http://www.ine.gov.bo/ }\end{array}$ & $\begin{array}{l}\text { Instituto Nacional de Estadistica de } \\
\text { Bolivia. http://www.ine.gov.bo/ }\end{array}$ \\
\hline Brazil & Household Survey & IPEA, www.ipea.gov.br & $\begin{array}{l}\text { Ferreira, Lanjouw and Neri (2000) } \\
\text { "A new poverty profile for Brazil } \\
\text { using PPV, PNAD and census } \\
\text { data", PUC-Rio, Department of } \\
\text { Economics, TD \# } 418\end{array}$ \\
\hline Chile & $\begin{array}{l}\text { Household Survey: Gran Santiago's } \\
\text { Employment And Unemployment } \\
\text { Survey (Encuesta de Ocupacion y } \\
\text { Desocupacion de Gran Santiago). } \\
\text { National Institute of Statistics (Instituto } \\
\text { Nacional de Estadisticas (INE)). }\end{array}$ & $\begin{array}{l}\text { Monthly Memory, Central Bank of Chile. } \\
\text { http://www.bcentral.cl/esp/ }\end{array}$ & $\begin{array}{l}\text { Source: “Social Equity / Poverty } \\
\text { Reduction and Poverty Targeted } \\
\text { Investment (PTI)”, June 2001, Inter } \\
\text { American Development Bank }\end{array}$ \\
\hline Colombia & $\begin{array}{l}\text { Household Survey: National } \\
\text { Household Survey (Encuesta } \\
\text { Nacional de Hogares), carried out by } \\
\text { the National Department of Statistics } \\
\text { (DANE) and the National Department } \\
\text { of Planning (DNP) }\end{array}$ & $\begin{array}{l}\text { "Estadísticas Monetarias y Financieras". } \\
\text { Banco de la República; Función Pública. }\end{array}$ & $\begin{array}{l}\text { DANE (the Colombian statistical } \\
\text { Agency) Source: Colombia poverty } \\
\text { report, World Bank. }\end{array}$ \\
\hline Costa Rica & Household Survey & $\begin{array}{l}\text { Ministerio de Planificación Nacional y } \\
\text { Política Económica (MIDEPLAN), } \\
\text { http://www.mideplan.go.cr/sides/economic } \\
\text { o/03-11.htm }\end{array}$ & $\begin{array}{l}\text { Poverty Assessment report, } 1997 \text {, } \\
\text { Annex 3, p. } 40 .\end{array}$ \\
\hline Dom. Rep. & T & $\begin{array}{l}\text { http://www.oit.or.cr/oit/papers/mer_trab_re } \\
\text { p_dom.pdf }\end{array}$ & Poverty assessment, 2001 \\
\hline Ecuador & LFS & Central Bank of Ecuador & Only $2 \$$ /day available \\
\hline El Salvador & LSMS & http://www.pridex.com.sv/mdobra2.htm & $\begin{array}{l}\text { DIGESTYC. Encuestas de Hogares } \\
\text { de Propósitos Múltiples. }\end{array}$ \\
\hline Guatemala & LSMS & $\begin{array}{l}\text { Guatemala: Livelihoods, Labor Markets, } \\
\text { and Rural Poverty. Renos Vakis, World } \\
\text { Bank. April, } 2002\end{array}$ & $\begin{array}{l}\text { Guatemala Poverty Assessment, } \\
\text { 2002. World Bank. }\end{array}$ \\
\hline Guyana & Household Survey & $\begin{array}{l}\text { Economic Research Institute. } \\
\text { http://www.erieri.com/freedata/hrcodes/ind } \\
\text { ex.htm?guyana.htm }\end{array}$ & $\begin{array}{l}\text { Structural adjustment and } \\
\text { agriculture in Guyana: From crisis } \\
\text { to recovery. Sectoral Activities } \\
\text { Programme. Industrial Activities } \\
\text { Branch. Working Paper. ILO }\end{array}$ \\
\hline Honduras & Household Survey & $\begin{array}{l}\text { http://www.imf.org/External/NP/prsp/2001/ } \\
\text { hnd/01/083101.pdf }\end{array}$ & $\begin{array}{l}\text { Honduras Poverty Diagnostic } \\
\text { Report, } 2000\end{array}$ \\
\hline Jamaica & LFS & $\begin{array}{l}\text { http://www.ilocarib.org.tt/digest/jamaica/ja } \\
\text { m19.html }\end{array}$ & SLC, 2001 \\
\hline Mexico & LFS & $\begin{array}{l}\text { Mexican Statistical, Geographical, and } \\
\text { Information Institute }\end{array}$ & $\begin{array}{l}\text { Inegi/cepal updated by World Bank } \\
\text { staff }\end{array}$ \\
\hline Nicaragua & LSMS & $\begin{array}{l}\text { http://www.bcn.gob.ni/estadisticas/indicad } \\
\text { ores/ }\end{array}$ & $\begin{array}{l}\text { Nicaragua Poverty Assessment, } \\
\text { 2001. World Bank. }\end{array}$ \\
\hline Panama & Household Survey & $\begin{array}{l}\text { ILO } \\
\text { (http://www.oit.or.cr/oit/papers/sal_pn99.ht } \\
\text { m) }\end{array}$ & Poverty Assessment, 2000 \\
\hline Paraguay & LSMS & $\begin{array}{l}\text { Labor and Justice Ministry, } \\
\text { http://www.dgeec.gov.py/Publicaciones/bib } \\
\text { lioteca/CanastaBasica/ }\end{array}$ & $\begin{array}{l}\text { "Paraguay - Attacking poverty", } \\
\text { World Bank, } 2002\end{array}$ \\
\hline Peru & Household Survey & http://www.inei.gob.pe/ & $\begin{array}{l}\text { Poverty and social developments in } \\
\text { Peru, 1994-1997. World Bank, } \\
\text { 1999. }\end{array}$ \\
\hline Uruguay & $\begin{array}{l}\text { Household Survey: Continuing } \\
\text { Household Survey (National Institute } \\
\text { of Statistics, INE) }\end{array}$ & $\begin{array}{l}\text { National Institute of Statistics, INE. } \\
\text { http://www.ine.gub.uy/banco\%20de\%20da } \\
\text { tos/ims/IMS\%20S-M-N\%20A.xls }\end{array}$ & $\begin{array}{l}\text { National Institute of Statistics } \\
\text { (Instituto Nacional de Estadística } \\
\text { (INE)) Source: “Maintaining Social } \\
\text { Equity...”, World Bank. }\end{array}$ \\
\hline Venezuela & Household Survey & $\begin{array}{l}\text { http://www.tradeport.org/ts/countries/vene } \\
\text { zuela/ecopol.html }\end{array}$ & Ruprah and Marcano \\
\hline
\end{tabular}


Table 3. Minimum wages in Latin America and the Caribbean

\begin{tabular}{|l|l|c|c|}
\hline Country & Year & monthly mw & $\begin{array}{l}\text { mw in PPP- } \\
\text { adjusted US\$ }\end{array}$ \\
\hline Paraguay & 2000 & 680168 & $\$ 546$ \\
\hline El Salvador & 1998 & 1083.6 & $\$ 446$ \\
\hline DR & 1997 & 2412 & $\$ 429$ \\
\hline Costa Rica & 1999 & 54938 & $\$ 423$ \\
\hline Chile & 2001 & 100000 & $\$ 335$ \\
\hline Colombia & 1999 & 236438 & $\$ 293$ \\
\hline Guatemala & 2000 & 712 & $\$ 289$ \\
\hline Honduras & 1999 & 1419 & $\$ 221$ \\
\hline Brazil & 1999 & 136 & $\$ 205$ \\
\hline Argentina & 2000 & 200 & $\$ 200$ \\
\hline Panama & 1998 & 206 & $\$ 185$ \\
\hline Guyana & 1999 & 19000 & $\$ 181$ \\
\hline Peru & 1999 & 345 & $\$ 124$ \\
\hline Bolivia & 1999 & 330 & $\$ 90$ \\
\hline Jamaica & 1998 & 800 & $\$ 75$ \\
\hline Ecuador & 1998 & 762967 & $\$ 75$ \\
\hline Venezuela & 1998 & 100000 & $\$ 54$ \\
\hline Mexico & 1999 & 888.81 & $\$ 50$ \\
\hline Uruguay & 1998 & 990 & $\$ 45$ \\
\hline Nicaragua & 2001 & 1000 & NA \\
\hline
\end{tabular}

Note: The minimum wage line for Dominican Republic is for large companies. Small and medium size companies have minimum wages that are 72 and 64 percent respectively of the large company level. The definition of a Large company is: Companies with installations or goods, or the sum of them, for value above of RD\$500.000.00. Medium company: installations or goods, or the sum of them, for value between $\mathrm{RD} \$ 200.000 .000$ and $\mathrm{RD} \$ 500.000 .00$. Small company: installations or goods, or the sum of them, for value below RD\$200.000.00; PPP conversion factors are obtained from the "GDF and WDI central (August 2002)" World Bank database 
Table 4: Percent in each category who earn at or below the minimum wage

\begin{tabular}{|c|c|c|c|}
\hline & Argentina & Brazil & México \\
\hline \multicolumn{4}{|l|}{ Role in household } \\
\hline Head & 10.1 & 3.4 & 4.2 \\
\hline Spouse & 19.8 & 8.5 & 14.3 \\
\hline Child & 20.9 & 10 & 9.9 \\
\hline \multicolumn{4}{|l|}{ Age } \\
\hline $12-17$ & 70 & 16.5 & 25.6 \\
\hline $18-24$ & 20.3 & 9.9 & 6.5 \\
\hline $25-64$ & 12.4 & 5.6 & 6.03 \\
\hline $65+$ & 31.7 & 6.4 & 24.4 \\
\hline \multicolumn{4}{|l|}{ Education } \\
\hline None & --- & 14.2 & 22.7 \\
\hline Primary & 24.6 & 9.5 & 11.9 \\
\hline Secondary & 12.9 & 5.2 & 6.5 \\
\hline Higher & 6.5 & --- & 2.2 \\
\hline \multicolumn{4}{|l|}{ Sex } \\
\hline Male & 11.9 & 4.4 & 4.5 \\
\hline Female & 19.9 & 10.8 & 13.2 \\
\hline \multicolumn{4}{|l|}{ Sector } \\
\hline Self-employment & 23.7 & 3.4 & 13.9 \\
\hline Informal wage & 31.7 & 11.4 & 16.9 \\
\hline Formal wage & 4.7 & 7.0 & 0.5 \\
\hline \multicolumn{4}{|l|}{ Wealth quintile } \\
\hline $1^{\text {st }}$ & 24.5 & --- & 14.6 \\
\hline $2^{\text {nd }}$ & 15.4 & --- & 10.3 \\
\hline $3^{\text {rd }}$ & 12.1 & --- & 8.4 \\
\hline $4^{\text {th }}$ & 10.5 & --- & 6.9 \\
\hline $5^{\text {th }}$ & 5.6 & --- & 4.1 \\
\hline
\end{tabular}

Source: Argentina and Mexico: Cunningham, Wendy (2002); Brazil: Neumark, Cunningham, Siga (forthcoming) 
Table 5: Ratio of each sub-group's share of the minimum wage population, relative to their share of the total workforce (full time workers only)*

\begin{tabular}{|l|c|c|c|c|c|c|c|}
\hline & \multicolumn{2}{|c|}{ Age } & \multicolumn{2}{c|}{ Education } & \multicolumn{2}{c|}{ Sector } & Gender \\
\hline & $\begin{array}{c}\mathbf{1 6 - 1 9} \\
\text { years }\end{array}$ & $\begin{array}{c}\mathbf{5 5 - 6 4} \\
\text { years }\end{array}$ & $\begin{array}{c}\text { no } \\
\text { school }\end{array}$ & $\begin{array}{c}\text { primary } \\
\text { school }\end{array}$ & $\begin{array}{c}\text { informal } \\
\text { employee }\end{array}$ & $\begin{array}{c}\text { self- } \\
\text { employed }\end{array}$ & Female \\
\hline Argentina & na & na & na & 2.0 & na & na & 1.3 \\
\hline Bolivia & 1.6 & 3.0 & 2.1 & 1.9 & 1.0 & 1.5 & 1.0 \\
\hline Brazil & 2.1 & 0.9 & 1.4 & 1.2 & 1.8 & 0.5 & 1.4 \\
\hline Chile & 1.7 & 0.7 & 1.7 & 1.5 & 1.9 & na & 1.1 \\
\hline Colombia & 1.0 & 0.7 & 1.2 & 1.2 & 1.4 & 0.7 & 1.0 \\
\hline Costa Rica & 1.5 & 1.2 & 0.6 & 1.5 & Na & na & 1.0 \\
\hline Ecuador & 0.4 & 0.8 & 0.7 & 1.1 & 0.9 & 0.9 & 0.9 \\
\hline El Salvador & 1.4 & 0.3 & 1.4 & 1.6 & 1.0 & na & 1.1 \\
\hline Guatemala & 1.5 & 1.2 & 1.1 & 0.9 & 2.0 & 0.7 & 1.0 \\
\hline Guyana & 1.1 & 1.1 & 1.7 & 0.8 & na & 0.4 & 1.1 \\
\hline Honduras & 0.3 & na & 1.4 & na & 0.4 & na & 1.3 \\
\hline Jamaica & 1.8 & 1.9 & 6.5 & 1.6 & 1.5 & 3.0 & 1.2 \\
\hline Mexico & 1.9 & 1.6 & 3.4 & 1.3 & 3.7 & 1.7 & 1.3 \\
\hline Nicaragua & 1.1 & 1.1 & 1.2 & 0.9 & na & na & 1.1 \\
\hline Panama & 1.3 & 0.7 & 0.9 & 1.3 & 0.9 & 0.9 & 1.0 \\
\hline Paraguay & 0.3 & 0.8 & 0.3 & 0.9 & 0.9 & na & 0.8 \\
\hline Peru & 1.2 & 0.4 & 0.2 & 1.0 & 1.2 & 0.4 & 0.8 \\
\hline Uruguay & 2.6 & 1.0 & 1.7 & 1.4 & na & na & 1.3 \\
\hline Venezuela & 1.2 & 0.8 & 0.8 & 1.1 & 1.2 & 0.7 & 1.1 \\
\hline
\end{tabular}

* omitted categories are, respectively, age 20-54, male, formal employee, and secondary school or above. "na" indicates that data were not available to generate the statistic. Each row is calculated as [(number in group $\mathrm{x}$ that earns the minimum wage)/(number in group $\mathrm{x}+\mathrm{y}$ that earns the minimum wage) $] /[$ (number in group $\mathrm{x}) /($ number in group $\mathrm{x}=\mathrm{y})]$; where $\mathrm{x}$ is a group listed in the first row of the table and $\mathrm{y}$ is the complement of $\mathrm{x}$ in the labor force. A value greater than 1 indicates that the reference group is over-represented among the minimum wage population. 
Table 6: Ratio of each sub-group's share of the sub-minimum wage population, relative to their share of the total workforce (full time workers only)*

\begin{tabular}{|l|c|c|c|c|c|c|c|}
\hline & \multicolumn{2}{|c|}{ Age } & \multicolumn{2}{c|}{ Education } & \multicolumn{2}{c|}{ Sector } & Gender \\
\hline & $\begin{array}{c}\mathbf{1 6 - 1 9} \\
\text { years }\end{array}$ & $\begin{array}{c}\mathbf{5 5 - 6 4} \\
\text { years }\end{array}$ & $\begin{array}{c}\text { no } \\
\text { school }\end{array}$ & $\begin{array}{c}\text { Primary } \\
\text { sch }\end{array}$ & $\begin{array}{c}\text { Informal } \\
\text { sector }\end{array}$ & $\begin{array}{c}\text { Self } \\
\text { employed }\end{array}$ & Female \\
\hline Argentina & na & na & 8.1 & 1.7 & na & na & 1.0 \\
\hline Bolivia & 1.9 & 1.6 & 2.6 & 1.3 & 0.8 & 1.9 & 1.8 \\
\hline Brazil & 2.2 & 1.6 & 3.3 & 1.2 & 2.3 & 1.8 & 1.0 \\
\hline Chile & 2.9 & 0.7 & 1.8 & 1.5 & 2.4 & na & 1.1 \\
\hline Colombia & 1.8 & 0.9 & 1.6 & 1.1 & 1.3 & 1.4 & 1.0 \\
\hline Costa Rica & 2.3 & 1.3 & 3.1 & 1.8 & 0.2 & n/a & 1.3 \\
\hline Ecuador & 1.9 & 1.0 & 1.8 & 1.5 & 1.0 & 1.1 & 1.1 \\
\hline El Salvador & 2.5 & 1.8 & 3.0 & 1.4 & 1.0 & n/a & 1.0 \\
\hline Guatemala & 1.7 & 2.8 & 2.1 & 1.2 & 1.2 & 2.0 & 1.1 \\
\hline Guyana & 1.8 & 0.8 & 1.4 & 1.1 & na & 1.0 & 1.3 \\
\hline Honduras & 1.9 & 1.3 & 1.1 & na & 1.5 & na & 1.5 \\
\hline Jamaica & 1.5 & 1.3 & na & 1.4 & 1.0 & 3.8 & 1.1 \\
\hline Mexico & 2.0 & 2.0 & 4.7 & 1.4 & 3.4 & 2.4 & 1.8 \\
\hline Nicaragua & 1.6 & 0.9 & 1.4 & 1.3 & n/a & na & 1.1 \\
\hline Panama & 2.8 & 1.1 & 2.4 & 1.7 & 1.7 & 1.3 & 0.7 \\
\hline Paraguay & 1.9 & 0.8 & 1.9 & 1.6 & 1.5 & na & 1.1 \\
\hline Peru & 2.4 & 0.9 & 2.6 & 1.4 & 2.0 & 1.1 & 1.2 \\
\hline Uruguay & 5.0 & 0.8 & 3.4 & 1.5 & n/a & na & 1.5 \\
\hline Venezuela & 1.9 & 1.2 & 2.1 & 1.2 & 1.7 & 1.4 & 1.2 \\
\hline
\end{tabular}

* omitted categories are, respectively, age 20-54, male, formal employee, and secondary school and above. "na" indicates that the data are not available to calculate the statistic. Each row is calculated as [(number in group $\mathrm{x}$ that earns the minimum wage)/(number in group $\mathrm{x}+\mathrm{y}$ that earns the minimum wage) $] /[($ number in group $\mathrm{x}) /($ number in group $\mathrm{x}=\mathrm{y}$ )]; where $\mathrm{x}$ is a group listed in the first row of the table and $\mathrm{y}$ is the complement of $\mathrm{x}$ in the labor force. A value greater than 1 indicates that the reference group is over-represented among the minimum wage population. 
Figure 1. Minimum wage/mean wage and Minimum wage/mean wages of low skilled

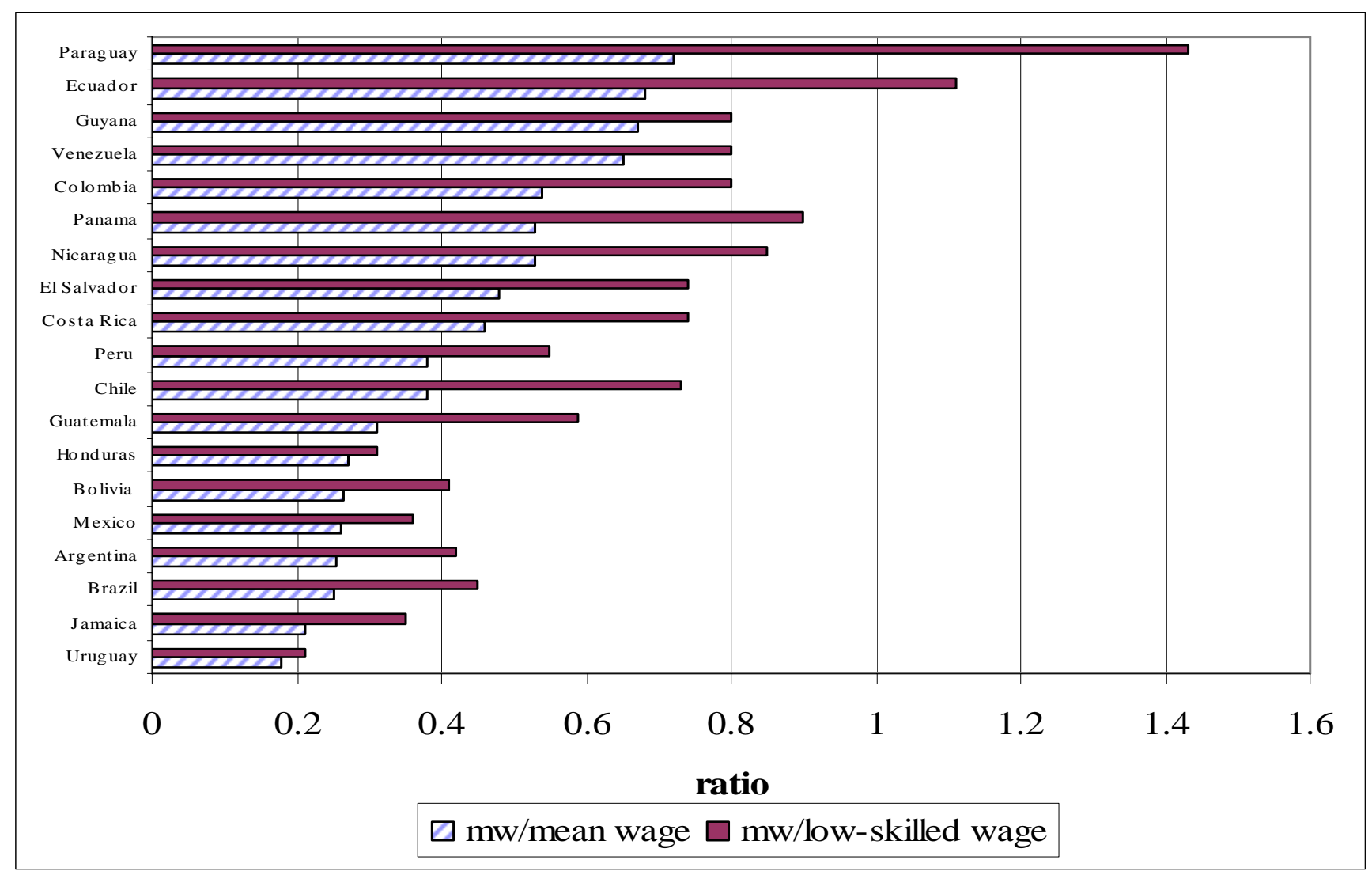

Figure 2. Minimum wages/poverty lines

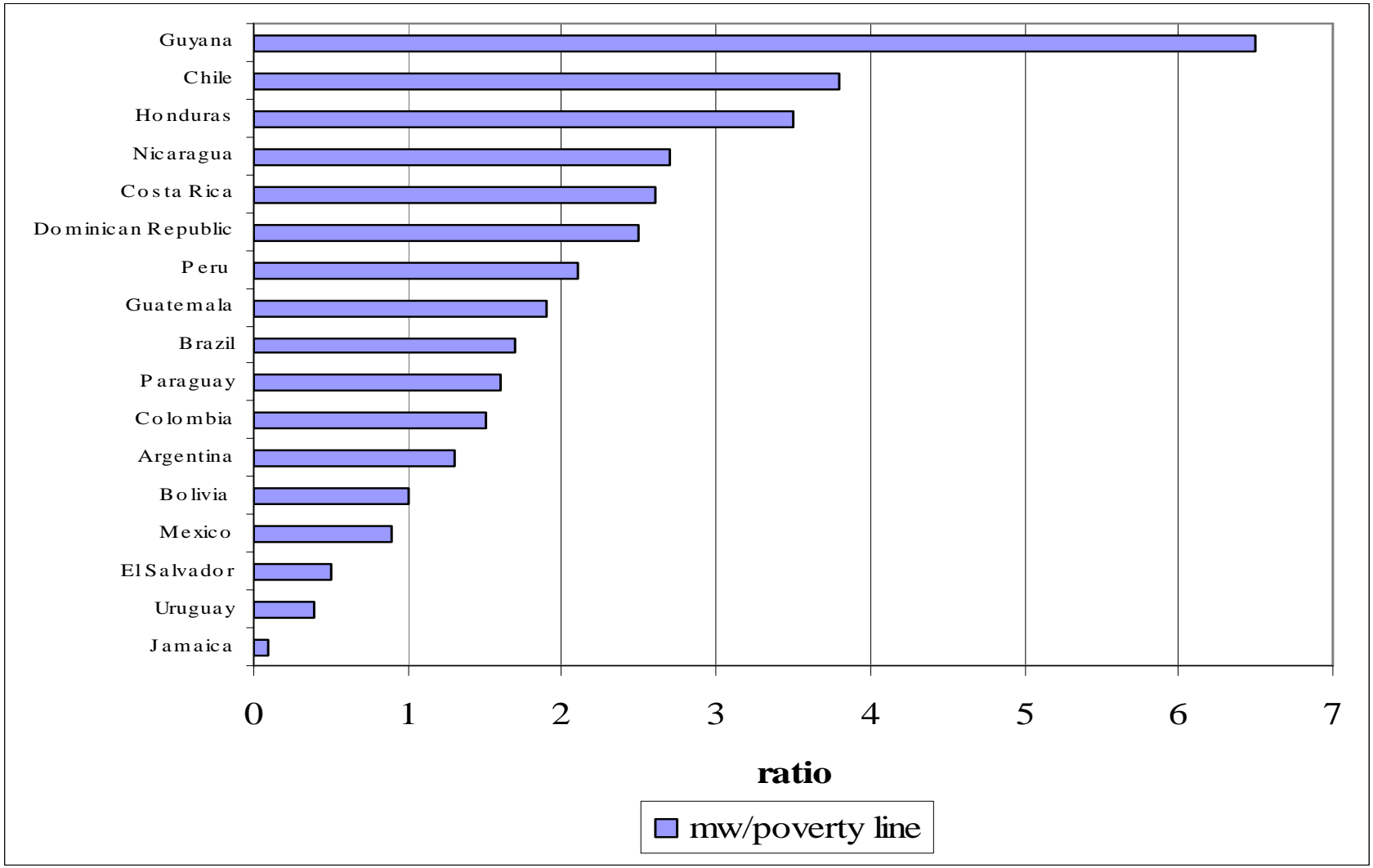




\section{Figure 3: Distribution of earnings compared to the minimum wage}

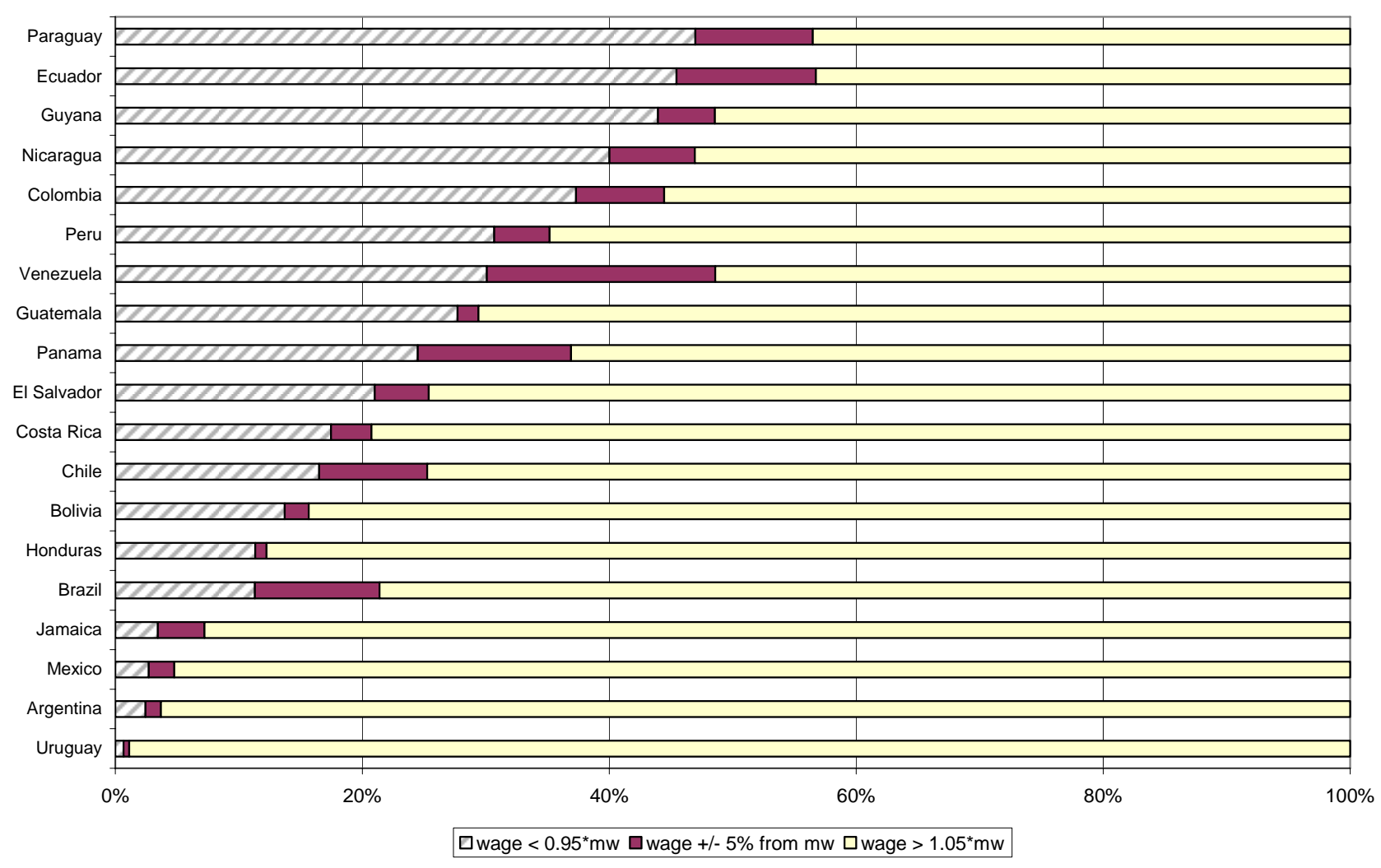


Figure 4. Kernel densities and cumulative distributions

(vertical line = minimum wage; on each set of axes: left graph for the informal sector and right graph for the formal sector)

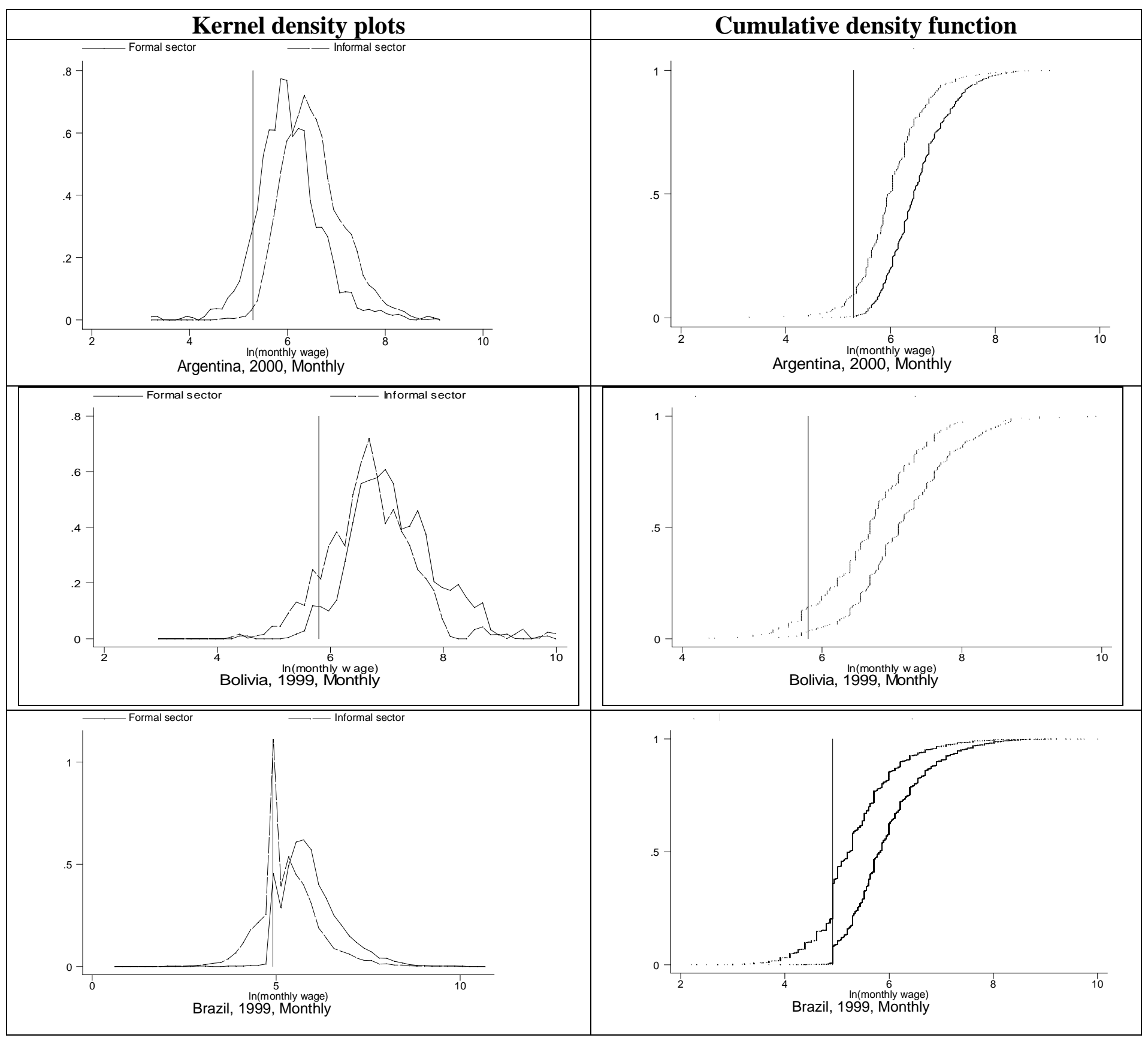




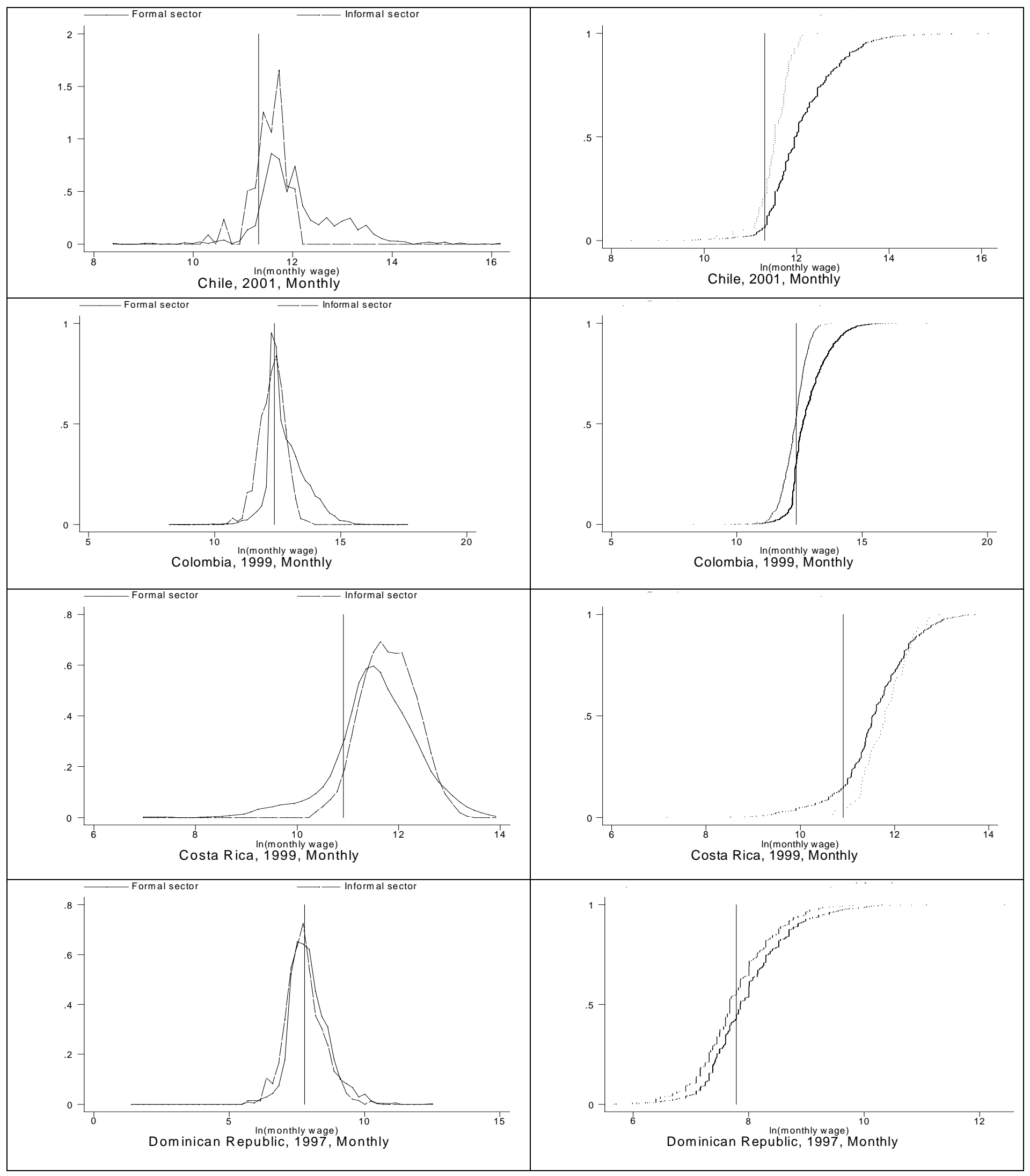




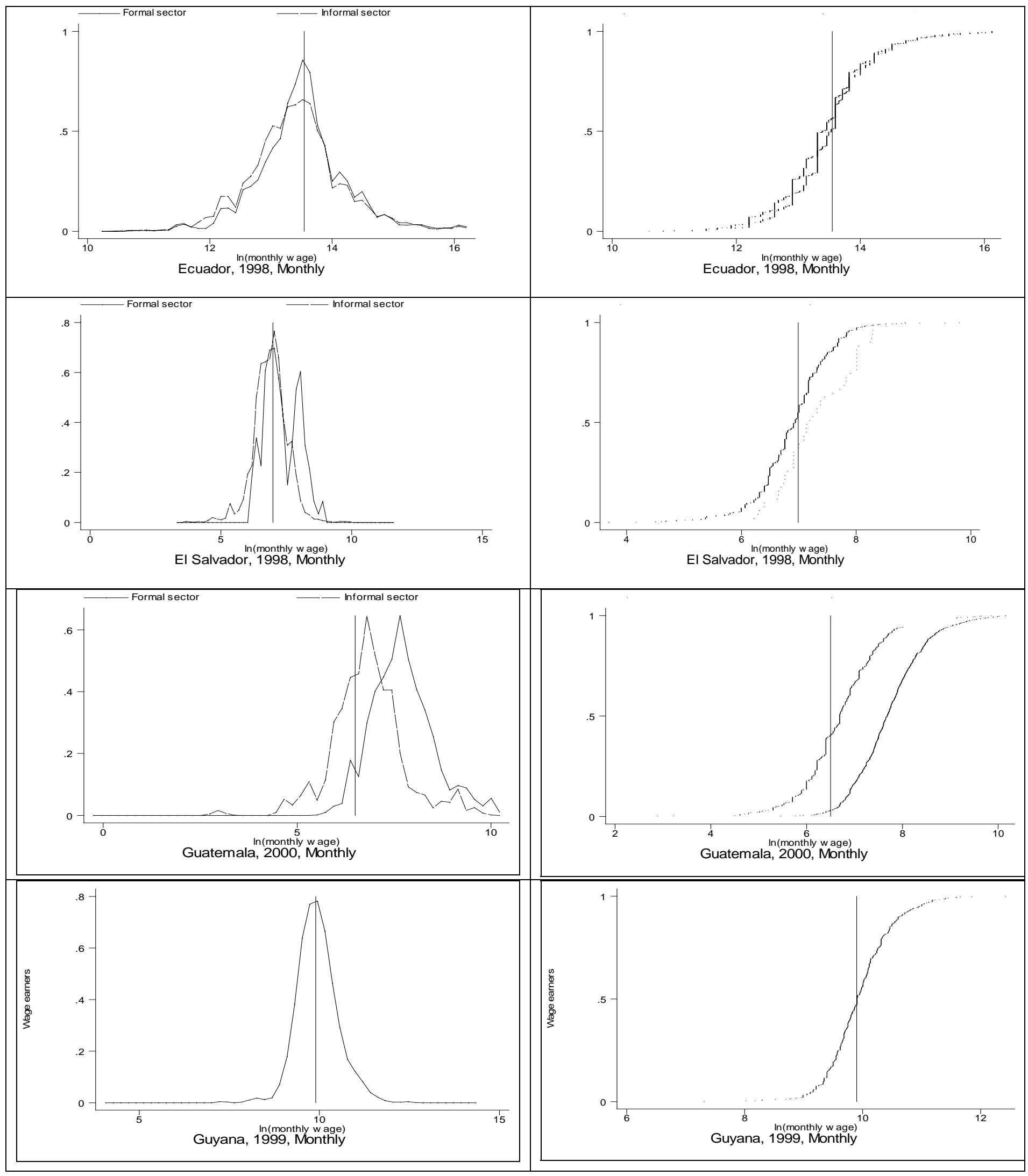




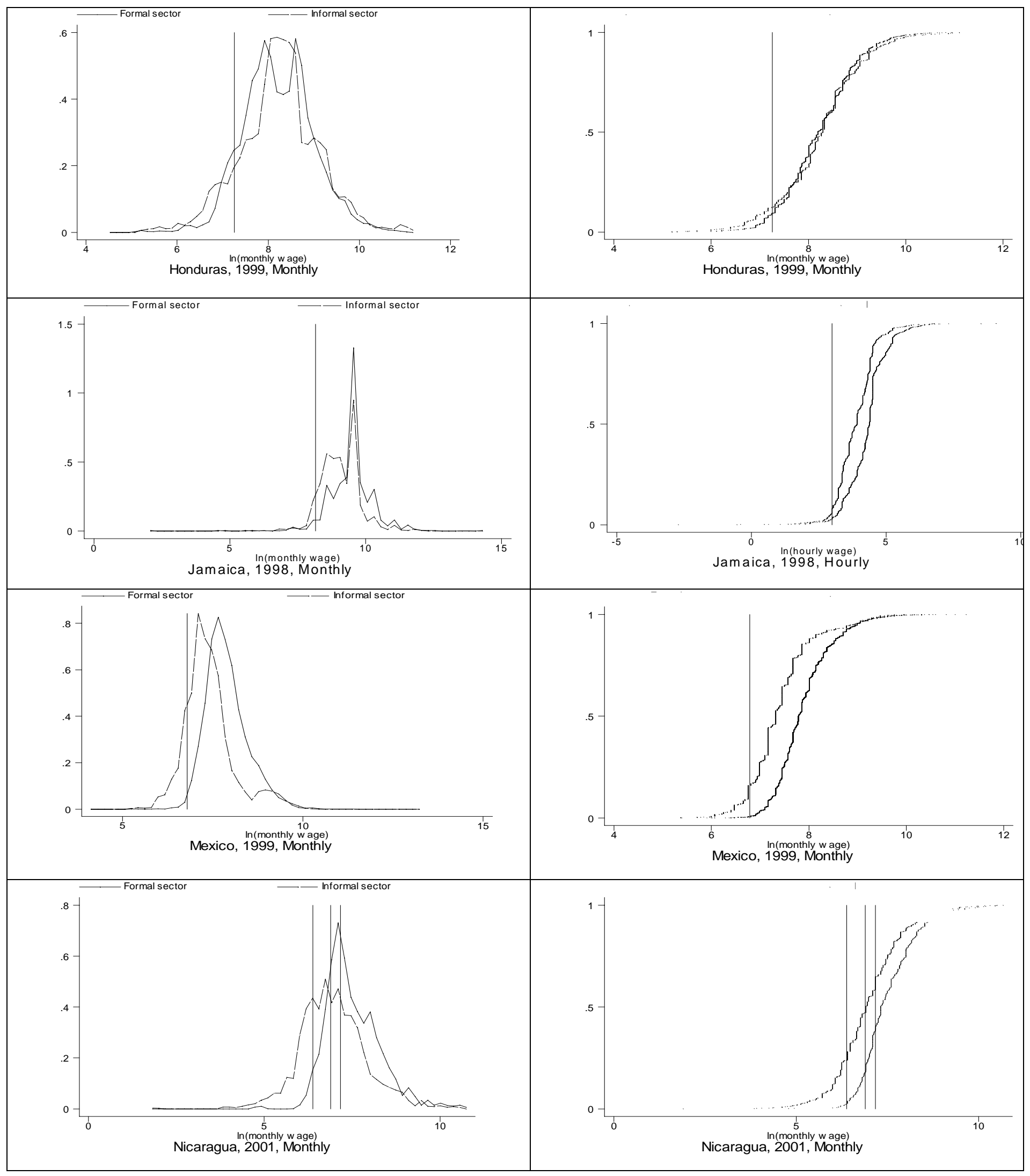




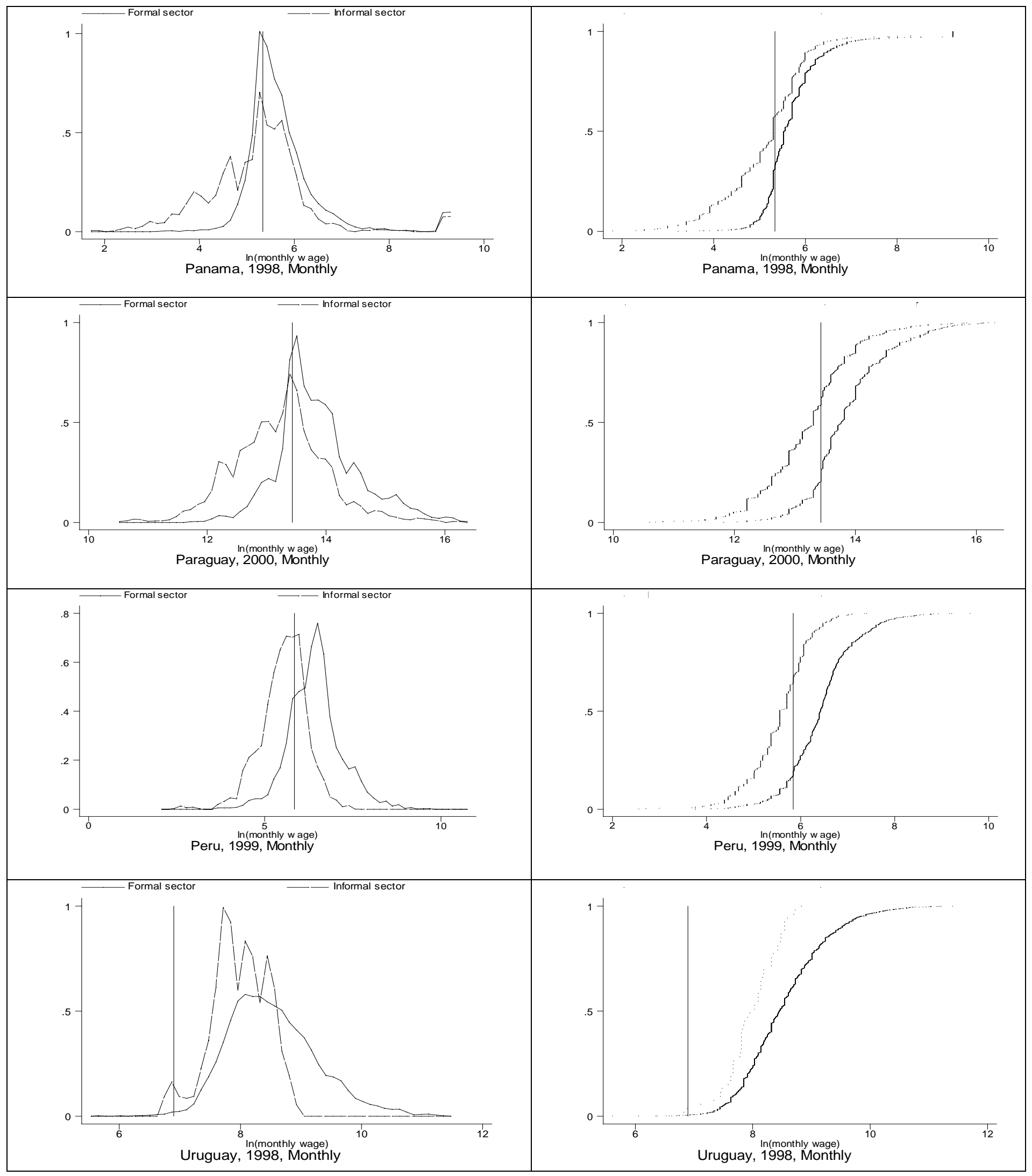




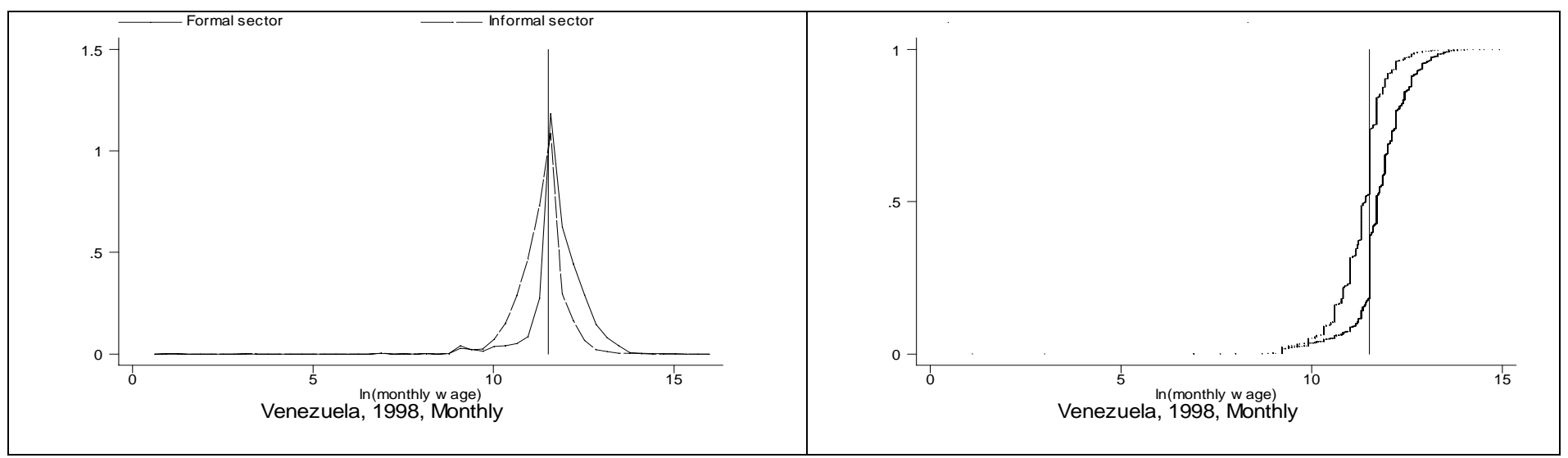

Notes: Dominican Republic: The minimum wage line is for large companies. Small and medium size companies have minimum wages that are 72 and 64 percent respectively of the large company level. The definition of a Large company is: Companies with installations or goods, or the sum of them, for value above of RD\$500.000.00. Medium company: installations or goods, or the sum of them, for value between RD $\$ 200.000 .000$ and RD $\$ 500.000 .00$. Small company: installations or goods, or the sum of them, for value below RD\$200.000.00. Ecuador: Average minimum wage. Nicaragua: The minimum wage differs across industries. The three lines indicate the three largest industries. Panama: Only companies with 11 or more employees are included in the analysis. Only industries with the same minimum wage are included; this means that agriculture, construction and "other" are excluded from the density plots. 
Figure 5. Numeraire effects, selected countries

On each set of axes: left graph for the informal sector and right graph for the formal sector

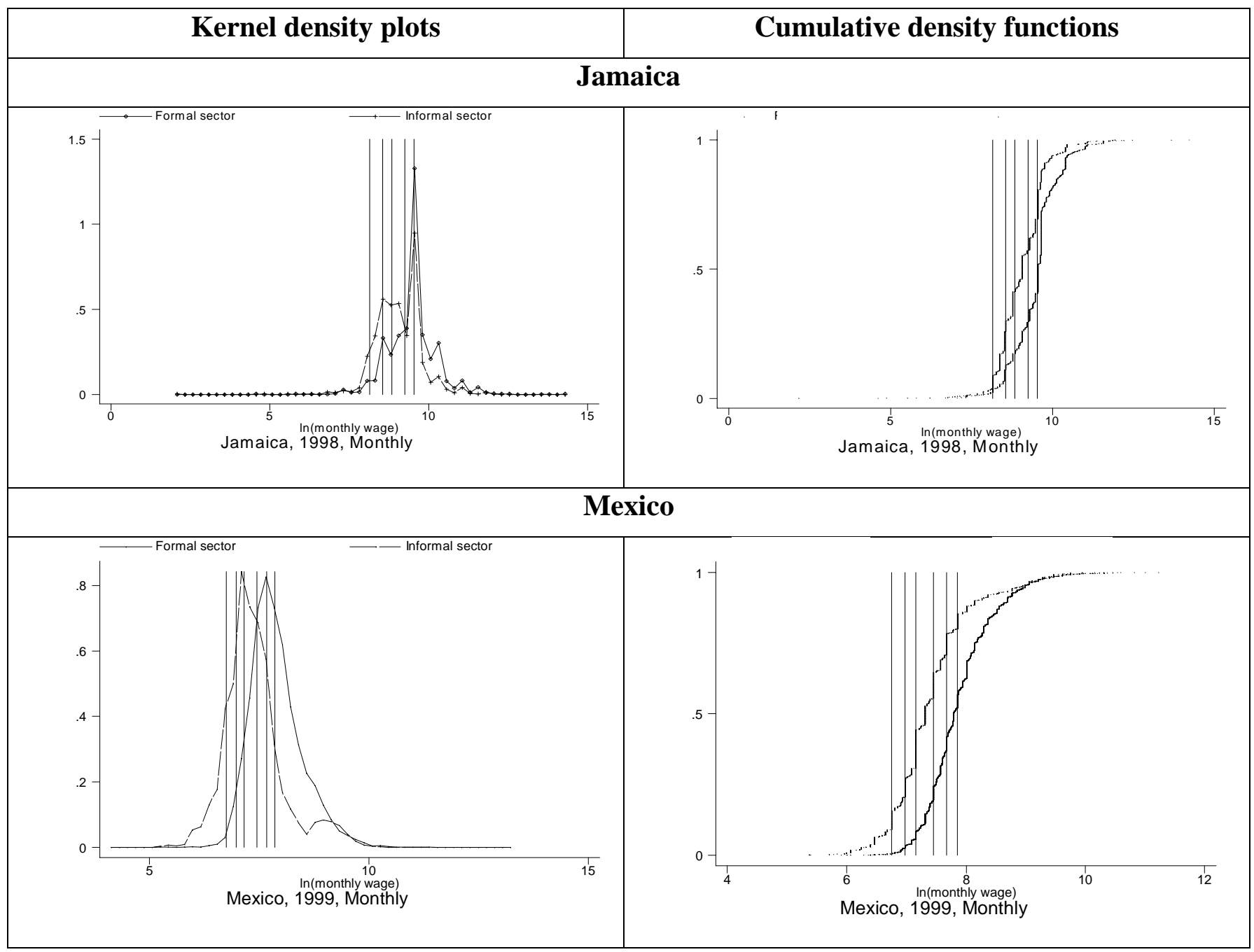

Note: The vertical lines for Jamaica are set at 1, 1.5, 2, 3 and 4 times the minimum wage. The vertical lines for Mexico are set at 1, 1.25, 1.5, 2, 2.5 and 3 times the minimum wage. 
Figure 6. Round number effects, selected countries

On each set of axes: left graph for the informal sector and right graph for the formal sector

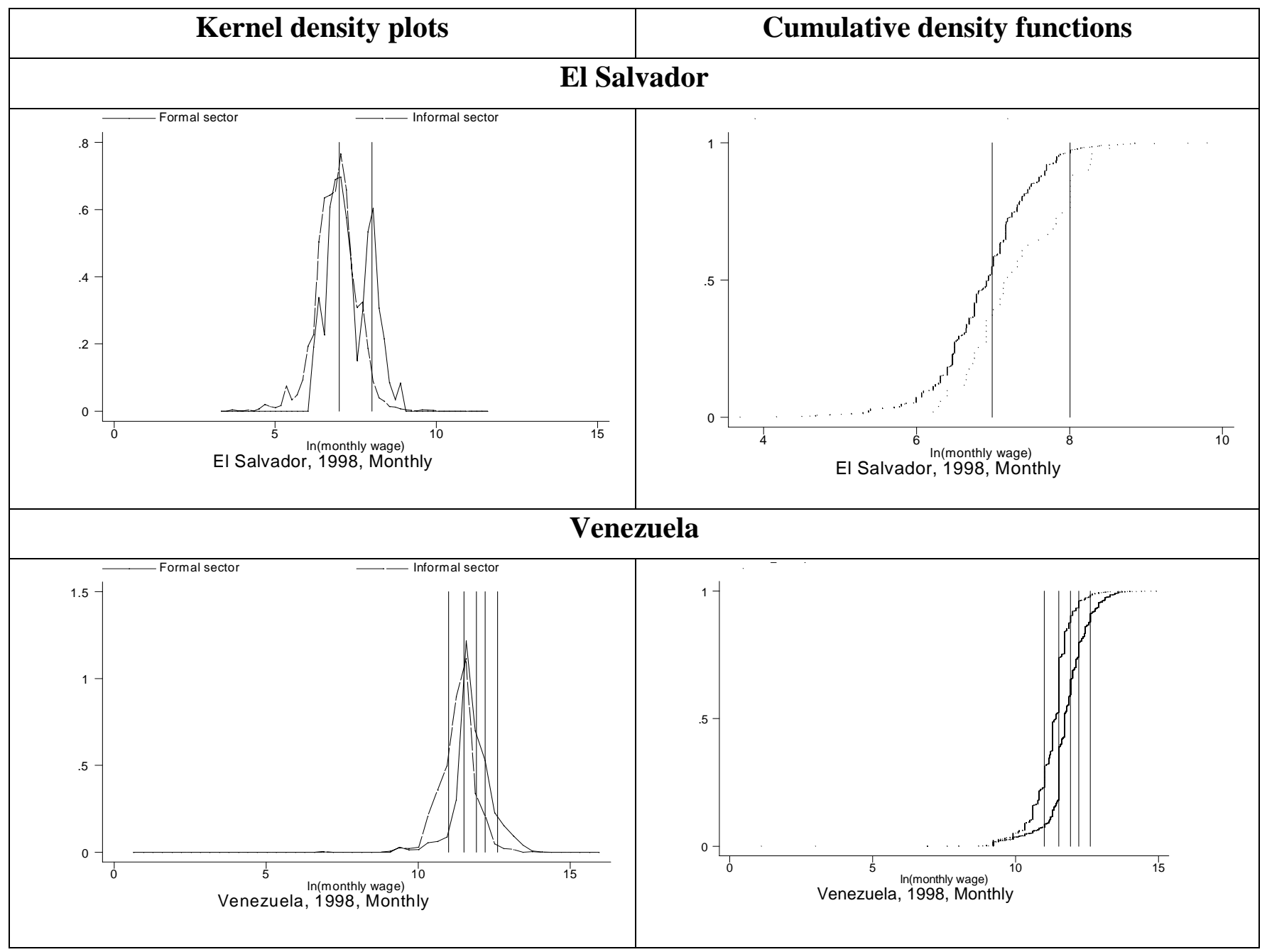

Note: The vertical lines for El Salvador are set at the minimum wage (left) and at 3000. The vertical lines for Venezuela are set at the minimum wage $(100,000)$ and 60000, 200,000 and 300,000. 
Figure 7. Formal Sector Kernel densities and cumulative distribution for educational groups for selected countries with a relatively $\underline{l o w} \mathbf{m w} / \mathbf{m e a n}$ ratio $($ vertical line $=$ minimum wage)

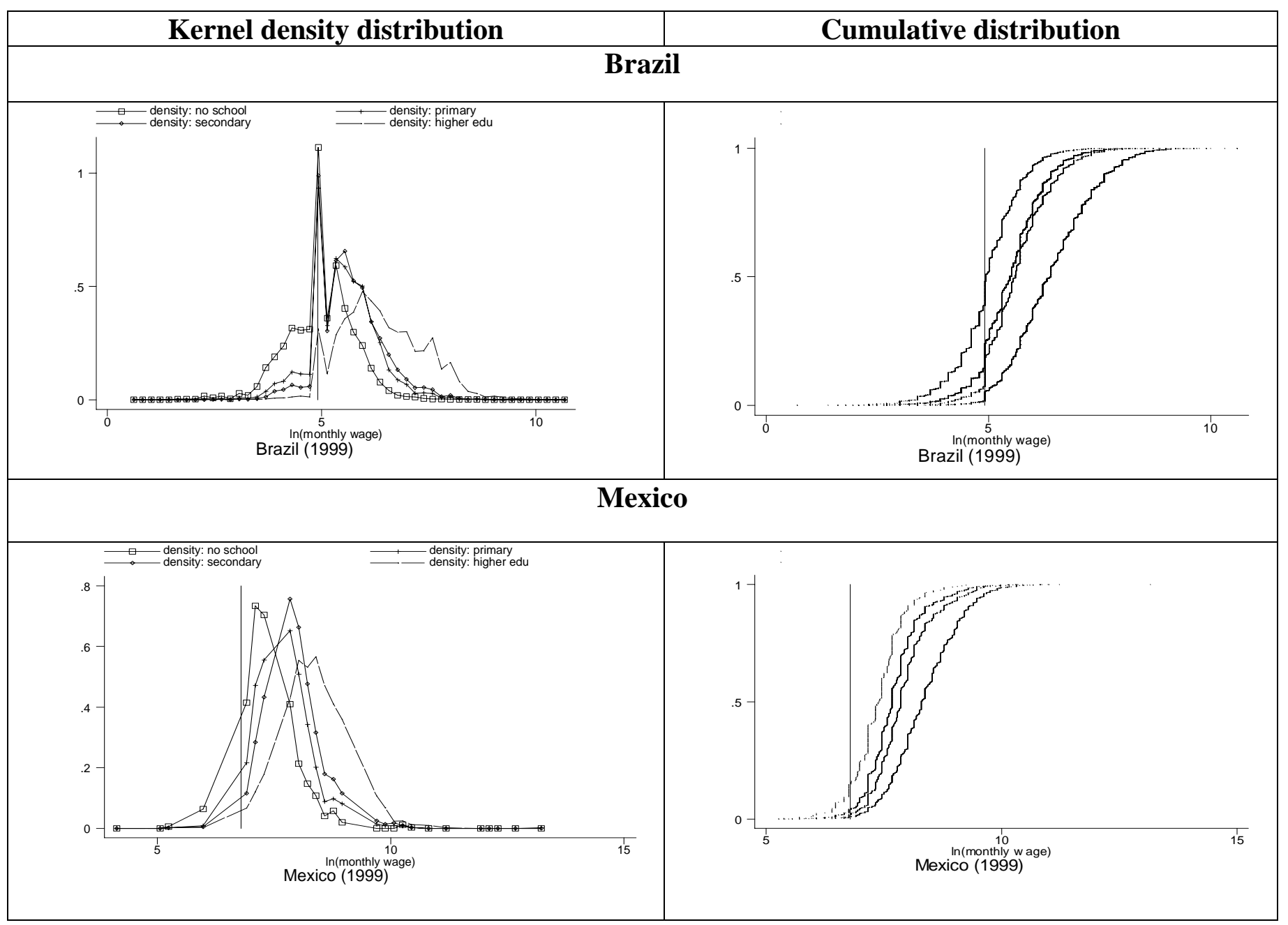


Figure 8. Kernel densities and cumulative distribution for educational groups for selected countries with a relatively high $\mathrm{mw} / \mathrm{mean}$ ratio (vertical line $=$ minimum wage)

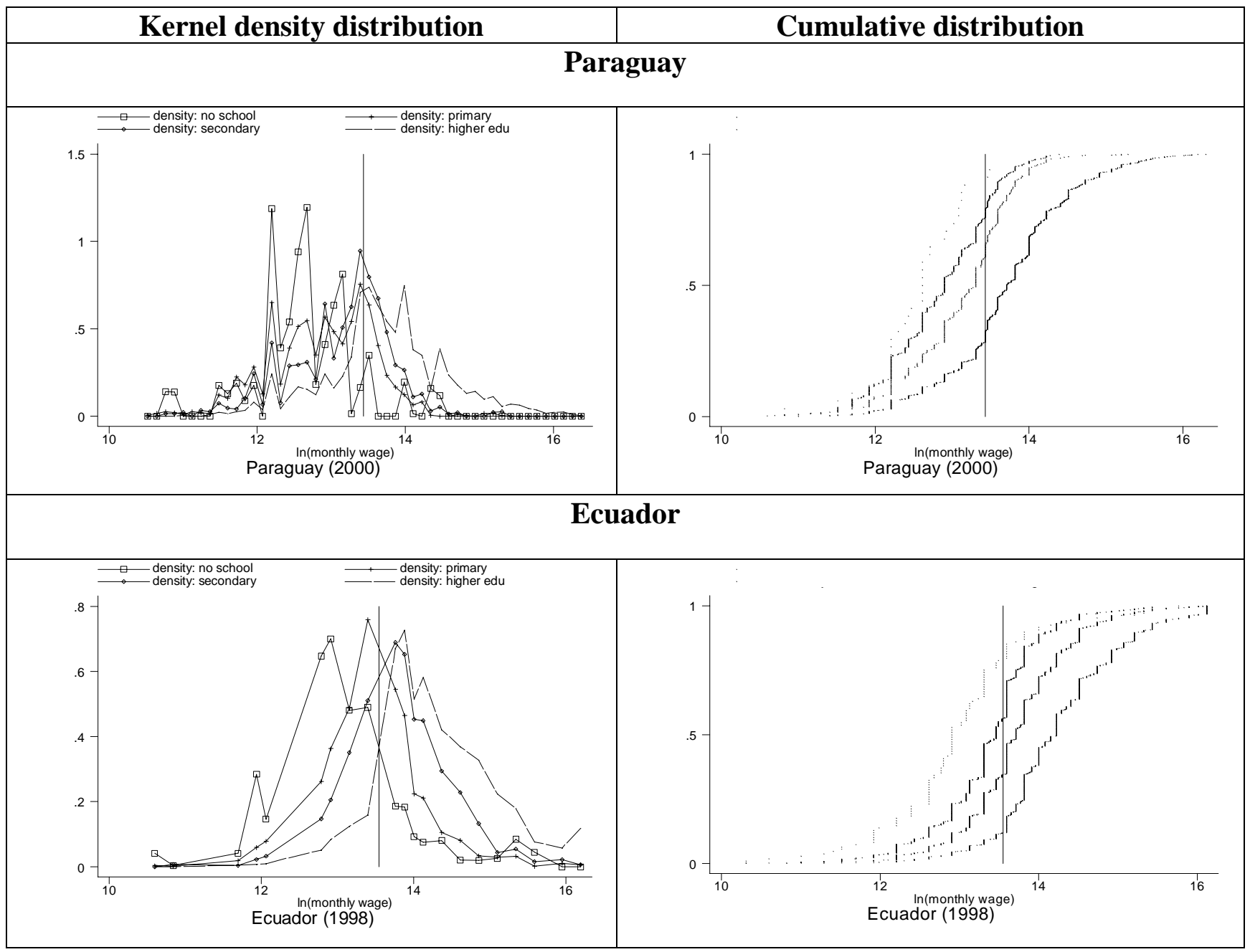

